\title{
Review \\ Cryopreservation of Agronomic Plant Germplasm Using Vitrification-Based Methods: An Overview of Selected Case Studies
}

\author{
Cesar Augusto Roque-Borda ${ }^{1}\left(\mathbb{D}\right.$, Dariusz Kulus ${ }^{2, *}{ }^{\circledR}$, Angela Vacaro de Souza ${ }^{3}$, Behzad Kaviani ${ }^{4}$ \\ and Eduardo Festozo Vicente ${ }^{3}$ (D)
}

Citation: Roque-Borda, C.A.; Kulus, D.; Vacaro de Souza, A.; Kaviani, B.; Vicente, E.F.

Cryopreservation of Agronomic Plant Germplasm Using

Vitrification-Based Methods: An Overview of Selected Case Studies. Int. J. Mol. Sci. 2021, 22, 6157. https://doi.org/10.3390/ ijms22116157

Academic Editor:

Pedro Martínez-Gómez

Received: 10 May 2021

Accepted: 4 June 2021

Published: 7 June 2021

Publisher's Note: MDPI stays neutral with regard to jurisdictional claims in published maps and institutional affiliations.

Copyright: (C) 2021 by the authors. Licensee MDPI, Basel, Switzerland. This article is an open access article distributed under the terms and conditions of the Creative Commons Attribution (CC BY) license (https:/ / creativecommons.org/licenses/by/ $4.0 /)$.
1 School of Agricultural and Veterinarian Sciences, São Paulo State University (UNESP), Jaboticabal 14884-900, SP, Brazil; cesar.roque@unesp.br

2 Laboratory of Ornamental Plants and Vegetable Crops, Faculty of Agriculture and Biotechnology, UTP University of Science and Technology in Bydgoszcz, Bernardyńska 6, 85-029 Bydgoszcz, Poland

3 School of Sciences and Engineering, São Paulo State University (UNESP), Tupã 17602-496, SP, Brazil; angela.souza@unesp.br (A.V.d.S.); eduardo.vicente@unesp.br (E.F.V.)

4 Department of Horticultural Science, Rasht Branch, Islamic Azad University, Rasht 4147654919, Iran; b.kaviani@yahoo.com

* Correspondence: dariusz.kulus@utp.edu.pl

\begin{abstract}
Numerous environmental and endogenous factors affect the level of genetic diversity in natural populations. Genetic variability is the cornerstone of evolution and adaptation of species. however, currently, More and More plant species and local varieties (landraces) are on the brink of extinction due to anthropopression and climate change. Their preservation is imperative for the sake of future breeding programs. Gene banks have been created worldwide to conserve different plant species of cultural and economic importance. Many of them apply cryopreservation, a conservation Method in which ultra-low temperatures $\left(-135^{\circ} \mathrm{C}\right.$ to $\left.-196^{\circ} \mathrm{C}\right)$ are used for long-term storage of tissue samples, with little risk of variation occurrence. Cells can be successfully cryopreserved in liquid nitrogen (LN) when the adverse effect of ice crystal formation and growth is Mitigated by the removal of water and the formation of the so-called biological glass (vitrification). This state can be achieved in several ways. The involvement of key cold-regulated genes and proteins in the acquisition of cold tolerance in plant tissues May additionally improve the survival of LN-stored explants. The present review explains the importance of cryostorage in agronomy and presents an overview of the recent works accomplished with this strategy. The Most widely used cryopreservation techniques, classic and Modern cryoprotective agents, and some protocols applied in crops are considered to understand which parameters provide the establishment of high quality and broadly applicable cryopreservation. Attention is also focused on the issues of genetic integrity and functional genomics in plant cryobiology.
\end{abstract}

Keywords: cryoprotectant; droplet-vitrification; encapsulation-dehydration; encapsulation-vitrification; gene banks; genetic integrity; Molecular Markers; somaclonal variation; vitrification

\section{Introduction}

The phylogenetic resource is defined as a genetic Material of plant origin that has real (economic) or potential (scientific and cultural) value for food and agriculture [1]. The genetic diversity of plants has been reduced in the past few decades and replaced by the uniformity of crops in the so-called genetic erosion process. This crop uniformization Makes agrotechniques easier but, consequently, less profitable species and varieties are abandoned. The loss of genetic variability limits the plants' capability to respond to environmental changes and favors the appearance of new pests or diseases. It also Makes further breeding programs More challenging. The importance of biological diversity conservation was recognized internationally in 196 countries and has generated a treaty that 
also includes the sustainable use of its components and fair and equitable participation in the benefits derived from the use of plant resources [2].

According to Lambers [3], one of the biggest concerns of biologists is that the rapid warming rates projected for the planet could lead Many species to perish. Climate change is altering environmental niches, forcing species to shift their habitat range [4]. They can suffer from extinction if the specific habitat disappears or becomes inaccessible, due to geographical barriers or the species' inability to disperse. Previous studies have provided regional or taxonomic estimates of biodiversity loss with a climate change contribution of $54 \%$, Making it difficult to neglect the severity of this problem $[3,5]$.

There is great interest in understanding how species can respond to climate change, but forecasts show divergences and incipient data. As of 2015, More than 130 studies have been carried out to identify the level of risk that climate change represents for species and the specific traits and characteristics that contribute to the risk. If climate change continues at the current rate, one in six species could face extinction [6]. Several regions, including South America and Oceania, face an increased hazard due to temperature change, generating global warming, which consequently causes the Melting of the glacier poles, destabilizing various ecosystems, and extinguishing natural resources [7]. The predictions for the 1980s were that about 20,000 species of higher plants, Medicinal plants, and forest trees would be in danger of extinction [8]. however, over the years, this problem has been exacerbated due to indiscriminate deforestation, overcollection, intensive farming, and pollution, causing a continuous depletion of genetic variability.

Due to all these factors, germplasm banks were created that store different plant Materials, to Maintain a collection of the possible genetic variations existing in the world [9]. This review aims to analyze the current strategies of biodiversity protection with particular attention focused on cryopreservation as a Method of long-term storage of plant Material and some of its applications Made in agronomy in recent years. Attention is also focused on the issues of genetic integrity and genomics in plant cryobiology.

\section{Preservation of Plant Genetic Resources}

Genetic resources of plants can be conserved in their natural habitat (in situ) or other sites (ex situ), depending on the storage capacities or resources available and the characteristics of the species (Figure 1). In situ is the process of protecting a species, animal, or plant threatened by extinction in its natural habitat (in place/on-site), acting or not in the habitat itself, or defending this species from its predators. In situ protection is Mainly provided by nature reserves and national parks. The benefit of preservation in situ is that recovering populations are Maintained in the environment in which their distinct properties develop. Preservation ex situ (off-site) can be used in part or in the entire population when preservation in situ presents insurmountable difficulties, usually resulting from a lack of complete control over the Many factors which influence the survival of individuals and, therefore, the genetic Makeup of the conserved population [10,11]. different ex situ systems emerge as a complementary Measure to preservation in situ, Mainly aimed at protecting genetic Material and ensuring its Maintenance over time, in viable conditions and with original genetic characteristics $[8,12]$.

The germplasm of species with orthodox seeds (i.e., dehydration-tolerant) can be conserved in various ways, such as field collections, greenhouses, seed banks, or in vitro. The in vitro preservation Methods are carried out by vegetative propagation and slow-growth storage [13-16] and cryopreservation [17]. As for species with recalcitrant seeds (with low viability), it is necessary to resort to cryopreservation or Maintain the vegetative Material in field collections or in vitro culture [18]. 


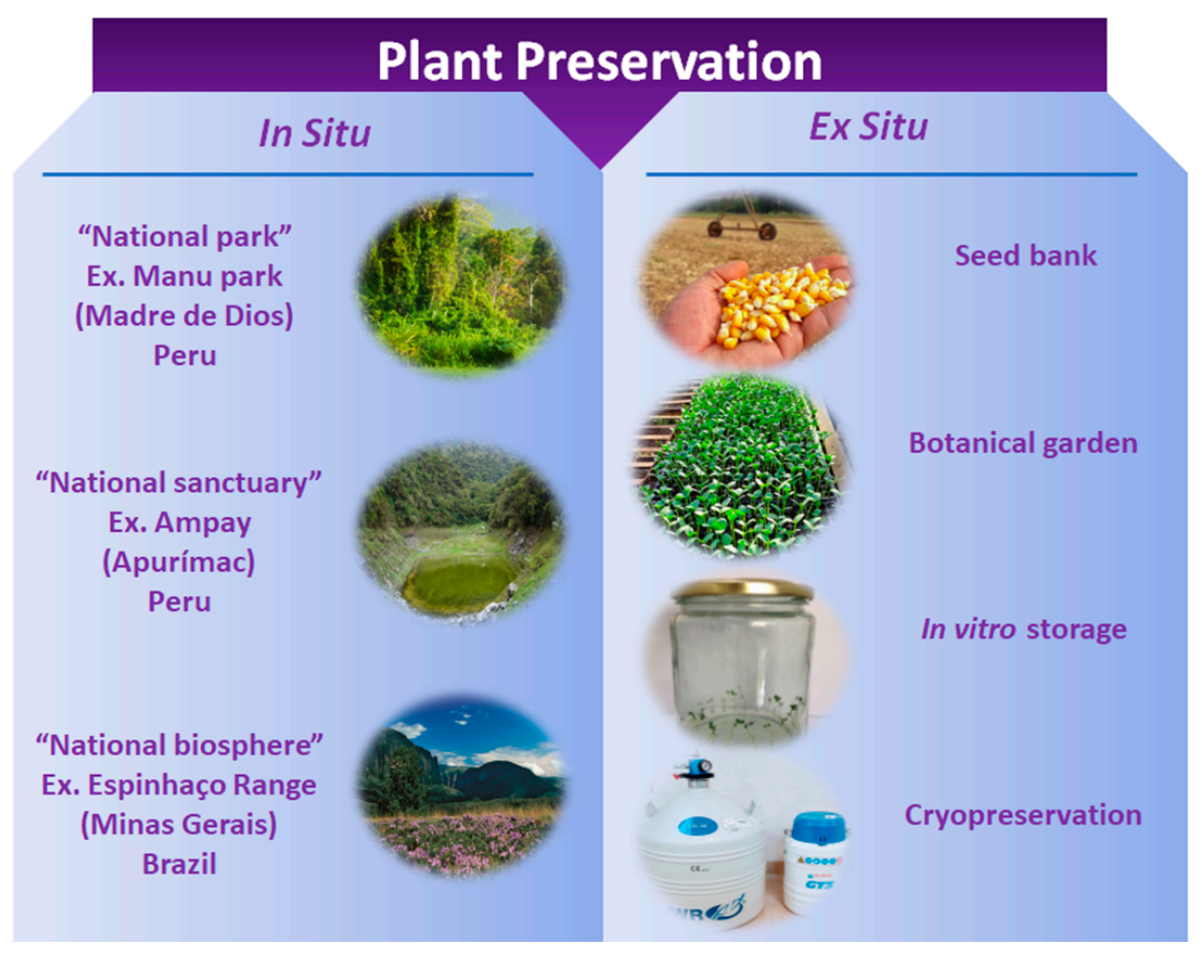

Figure 1. Basic strategies of plant preservation.

Field collections: it is a simple, well-known Method of biological diversity preservation. It can be carried out in situ in areas where it occurs naturally, trying to Maintain the diversity of living organisms, their habitats, and the interrelationships between organisms and the environment $[19,20]$. Alternatively, field collections May also refer to ex situ conservation if they are set off-site the natural habitat of a species, e.g., in plots, parks, gardens, etc.

In vegetatively propagated crops, such as potato (Solanum tuberosum L.), cassava (Manihot esculenta Crantz), and yam (Dioscorea), to Maintain genetic stocks (tubers and roots), they need to be stored and grown annually in nurseries. This is time-consuming and problematic, as well as requiring a lot of space and work. Moreover, the Material can be exposed to pests and pathogens and there is often a risk of germplasm loss [21]. Therefore, researchers are searching for complimentary preservation Methods.

Seed banks: are used for the storage of high-quality orthodox seeds (or pollen) in plastic bags, vials, or glass jars in a controlled environment (low temperature and humidity). Working and active collections are refrigerated $\left(\right.$ at $\left.5{ }^{\circ} \mathrm{C}\right)$. Longer storage of base collections is possible after (deep)freezing of seeds $\left(-20 ;-80^{\circ} \mathrm{C}\right)$. depending on the container used, storage temperature, and seed viability, the collections Must be periodically regenerated, and the produced plants are further selected to replenish seed stocks. Consequently, Most gene banks also Maintain field collections [17].

In vitro preservation: in vitro storage is an essential part of the overall strategy for the preservation and exchange of plant genetic resources worldwide [22]. In vitro germplasm banks conserve plant genetic resources under controlled aseptic conditions and involve various cell and tissue culture techniques, as well as synthetic seeds [23]. In vitro culture of slow growth is widely used to obtain Medium-term storage of tropical species explants, crops with vegetative propagation (e.g., potato, banana, cassava), or endangered species [24]. This Method is also known as 'reduced or minimal growth' because it is based on decreased cell division and plant Metabolism. Its objective is to increase the longevity of in vitro cultures without genetic alterations. Therefore, there is no total stoppage of cellular processes, but a decrease in the speed with which they occur and therefore in the frequency of subculturing plants to the fresh culture Medium to one per several Months or even years, depending on the species [18]. This growth reduction is usually obtained 
by decreasing the temperature and light intensity in the growth room and/or Modifying the composition of the culture Medium by increasing the concentration of osmotic agents or growth retardants.

\section{Cryopreservation}

Cryopreservation is an important tool for storing germplasm, developed in recent decades and already implemented in current germplasm banks, e.g., CIAT, Colombia; EMBRAPA, Brazil; CRI, Czech Republic; InHort, Poland; NARO, NIAS, NCSS, Japan; and Many others [9]. This Method consists of the use of ultra-low temperatures $\left(-135^{\circ} \mathrm{C}\right.$ to $-196^{\circ} \mathrm{C}$ ) of liquid nitrogen (LN), which allows cells to Maintain their viability and genetic stability. Cellular aging is interrupted due to nearly complete paralysis of its Metabolism, physiological and biochemical processes $[25,26]$.

The first report of successful cryopreservation of plant cells grown in vitro was from Quatrano [27] from hypocotyl-derived callus of aseptically germinated flaxseeds (Linum usitatissimum L.), using dimethyl sulfoxide (DMSO) as a protector against disruptions caused by cooling. Until now, it was known that cells with low water content, such as pollen, seeds, and dormant tissues of stress-tolerant species, May be subjected to the temperature of LN without suffering lethal damage. however, plant cells with higher water content present considerable problems due to the risk of ice crystal growth causing cell bursting. Sakai [28] demonstrated, for the first time, that successful cryopreservation involves the use of cryoprotectants and controlled cooling rates, and that this Method could be adapted for use with cells from a wide variety of plant species [29].

Among the several reasons that lead to the application of cryopreservation, one can Mention (1) facilitation of hybridization between plants that flower at different times; (2) hybridization between plants that grow in different and distant places; (3) reduction in the spread of diseases by pollination vectors, and (4) long-term Maintenance of highquality germplasm [30]. Cryopreservation minimizes the risk of variation occurrence, both somaclonal variation (non-sexual) and gametoclonal variation, which May occur in tissue culture or field collections, respectively. Therefore, it is possible to obtain cultures with vegetative propagation and genetic uniformity of the clones.

In the particular case of recalcitrant seeds, which are sensitive to low temperature and humidity, the embryo is short-lived [31]. Several species of recalcitrant seeds and agricultural importance are known, such as coconut tree (Cocos nucifera L.), palm oil (Elaeis guineensis Jacq.), coffee (Coffea arabica L.), Mango (Magnifera L.), chestnut (Castanea sativa Mill.), and walnut (Juglans L.) [32-34], in which germplasm cannot be Maintained through seedbanks. The cryopreservation of whole embryos, their segments, or vegetative parts of plants (e.g., shoot tips) can help to overcome this eventuality [35,36].

According to Engelmann and Takagi [37], classic cryopreservation, or controlled/slow/ two-step cooling, and newer techniques based on rapid cooling are recognized as the two possible Methods for long-term storage (Table 1). The first is based on slow cooling of explants $\left(0.1-2.0^{\circ} \mathrm{C} \cdot \mathrm{min}^{-1}\right)$ down to $-40^{\circ} \mathrm{C}$ (or less often $-20^{\circ} \mathrm{C}$ ); then, fast cooling by immersion in LN. There is a wide variety of LN freezers, automatic and Manual, in which the speed of cooling and rewarming can be regulated. The disadvantages of this Method include the complexity of the operation, the use of expensive and sophisticated equipment that controls the cooling rate, and the formation of ice crystals in extracellular solutions, causing water loss by cells in the so-called freeze-dehydration process [38,39]. The second cryopreservation Method is based on vitrification procedures, in which the solidification or vitrification of plant tissue solutions during the ultra-fast cooling process occurs. Vitrification is a physical process in which an aqueous solution solidifies into a Metastable amorphous solid known as the glass. In vitrification, the solidification of plant tissue solutions (both intracellular and extracellular) occurs by an extreme increase in their viscosity during the cryoprotective and ultra-fast cooling processes [21]. In this state, the formation of ice crystals is inhibited or minimized $[40,41]$. The extreme viscosity of the glass interrupts all chemical reactions that require Molecular diffusion, thus allowing the stability 
and latency of explants over time [42]. To obtain this state, the water content reduction and osmoprotection of the explants with sucrose and/or glycerol are often required, although some plant tissues can be cryopreserved just by physical partial desiccation, without the use of sucrose and/or glycerol (e.g., seeds, pollen, embryonic axes) [43]. After lowering the water content of the intra and extracellular solutions, rapid cooling in LN is performed.

Table 1. Synthesis of the essential steps involved in plant cryopreservation.

\begin{tabular}{cc}
\hline \multicolumn{2}{c}{ Cryopreservation Method } \\
\hline Classic Methods (Slow Cooling) & Modern Methods (Rapid Cooling) \\
\hline Establishment of in vitro culture or disinfection of tissues and organs taken directly from \\
the donor plant
\end{tabular}

Gradual and slow cooling at a certain cooling rate $\left(0.2-2{ }^{\circ} \mathrm{C} \cdot \mathrm{min}^{-1}\right)$, which can be achieved

by commercially available cryostats. This cooling is periodic up to $-20{ }^{\circ} \mathrm{C},-40{ }^{\circ} \mathrm{C}$,

$-70{ }^{\circ} \mathrm{C},-100{ }^{\circ} \mathrm{C}$ and, finally, $-196^{\circ} \mathrm{C}$ and at defined intervals

Fast cooling by direct immersion of the explants in LN

Storage of specimens in vials or straws in cryo-boxes in LN or, less often, its vapor phase Rewarming of samples (rapid in a water bath or at room temperature)

Elimination of the cryoprotectant by washing with a solution of high sucrose concentration (usually $1.2 \mathrm{M}$ )

Determination of viability (histochemically or by growth observation)

In vitro recovery of plants on a PGRs-supplemented Media (usually at reduced light conditions during the first two weeks of culture)

Acclimatization and transfer to ex vitro conditions

\section{Plant Material Used for Cryostorage}

The physiological state of the Mother plant is a key factor for the success of cryopreservation $[44,45]$. The cryopreservation efficiency depends on the position, age, and size of the explant. In vitro-derived shoot tips or apices are the Most common explant types used for this purpose. Both small (1 to $2 \mathrm{~mm}$ in length) and intermediate shoot tips or axillary buds ( 3 to $4 \mathrm{~mm}$ ) can achieve percentages of recovery comparable to the explants of noncryopreserved controls. This phenomenon, however, is not observed in larger Meristematic explants (5 to $6 \mathrm{~mm}$ ), which show a strong decrease in the percentage of recovery [46]. Occasionally, other explant types are also used for LN storage. Wang et al. [47] reported $56 \%, 72 \%$, and $32 \%$ shoot regrowth in cryopreserved shoot tips taken from in vitro shoots, adventitious buds regenerated from stem discs, and field-grown bulbs in onion (Allium cepa L.), respectively. Chen and Wang [48] developed a cryopreservation protocol for cell suspensions and protoplasts of carrot (Daucus carota L.), while Fábián et al. [49] used wheat (Triticum aestivum L.) egg cells excised from the ovaries. Carmona-Martín et al. [50], on the other hand, achieved $42-84 \%$ recovery of asparagus (Asparagus officinalis L.) when rhizome buds were used. Root explants isolated from in vitro-grown plants, as well as adventitious and hairy root cultures, have been recently used in several cryopreservation protocols, including alfalfa (Medicago truncatula Gaertn.) [51] and vanilla (Vanilla planifolia Andrews) [52]. They attract both scientific and commercial interest as an alternative 
source of plant-derived bioactive compounds with potential application in pharmaceutical, cosmetic, and natural health product industries [53].

\section{Cryoprotective Agents (CPAs)}

During cryopreservation, Many events occur that Modify the Molecular behavior of water and solutes. Thus, it is a challenge to avoid cytotoxicity and keep plant cell Metabolism stable during and after LN storage [54]. When cooling dilute aqueous solutions, thermodynamic and physical events occur in different temperature ranges, leading to nucleation. The heterogeneous nucleation occurs in biological systems when ice crystals are formed (about -5 to $-20{ }^{\circ} \mathrm{C}$ ); the homogeneous nucleation process (at less than $-40{ }^{\circ} \mathrm{C}$ ) takes place when this set of Molecules self-associate and form nucleated ice [55]. The presence of ice crystals is a threat to cell Membranes integrity, as the volume of ice is greater than that of water at the liquid phase. Therefore, nucleation and crystallization usually Must be avoided to Make the cells to be processed for storage at deep cryogenic temperatures and to be recovered with high levels of appropriate functionality [55].

Vitrification is the process that Modifies the viscosity of a solution to avoid nucleation and the formation of ice crystals at low temperatures [54]. To achieve this goal, it is necessary to use various substances, including CPAs, that can reduce the impact of cooling on plant cells [56]. Cryoprotective agents are used to increase osmolarity in the plant tissue and reduce the content of unbound water. Thus, CPAs are capable of Modifying phase changes during cooling. CPA solutes possess a wide range of Metabolic and biophysical effects. All these thermo-dependent events of Molecular interaction, diffusion, and heat flow can be studied using Fourier-transform infrared spectroscopy (ATR-FTIR), scanning electron cryomicroscopy (CRYO-SEM), differential scanning calorimetry (DSC), and thermogravimetric analysis (TGA); however, there are still Many of these aspects that are not fully understood [55].

Depending on their properties and functioning, two groups of CPAs can be distinguished, penetrating and non-penetrating.

\subsection{Penetrating CPAs}

Penetrating CPAs are low Molecular weight compounds that are permeable through the cell Membrane. They act essentially in the protoplast by replacing intracellular water before and during cooling and decrease the freezing point of water, which, combined with a slow or rapid cooling rate, reduces the formation and growth of ice crystals [55]. Penetrating CPAs also function by forming hydrogen bonds with biological Molecules as water Molecules are displaced. This is important for proper protein and dNA function $[57,58]$. The Molecular weights of CPAs vary between 32 and 212 da and the Most used penetrating CPAs are glycerol, dMSO, and 1,2-propanediol (propylene glycol or PG).

\subsection{Non-Penetrating CPAs}

Non-penetrating CPAs are substances of high Molecular weight that form hydrogen bonds with water. due to the large size of Molecules, they cannot penetrate the cell or enter it with extreme difficulty, reducing ionic forces outside the cell and Moderately decreasing the formation of ice crystals. Non-penetrating CPAs include carbohydrates such as polysaccharides, sucrose, and glucose being the Most used, or sugar alcohols (mannitol, sorbitol), which are effective due to their osmotic power and thus promote rapid cellular dehydration. To fully express their characteristics, non-penetrating CPAs are usually Mixed with penetrating cryoprotectants $[59,60]$.

The addition of the cryoprotectant generates osmotic stress in the cells, as it increases the osmolarity of the Medium. Cells are initially dehydrated to compensate for the osmotic force induced by the presence of CPA and then rehydrated after LN storage and rewarming of samples. The definition of the biophysical parameters of each cell type and the study of the interaction with CPA during the cooling and rewarming of the explant Must be defined to establish the physical limits that guarantee the survival of the cells [61]. differential 
scanning calorimetry (DSC) analyses can be used to help reveal the presence of intracellular ice within explants at key steps during the cryopreservation procedure [62].

\section{Osmoprotective Solutions}

Osmoprotective solutions are preparations with a Mixture of low or Moderately concentrated penetrating and non-penetrating CPAs. The Most common osmoprotective solution used in plant cryobiology is the so-called loading solution 1 (LS). It was developed by Nishizawa et al. [63] and is composed of $2.0 \mathrm{M}$ glycerol and $0.4 \mathrm{M}$ sucrose. Other loading solutions are also known (composed of sucrose, glycerol, dMSO, and/or ethylene glycol (EG) in various concentrations and combinations), although they are less popular (Table 2) [64]. The function of LS is to biophysically prepare the plant specimens to osmotic stress by exposure to a Moderately concentrated osmoticum, before severe dehydration with highly concentrated CPAs [65]. Sucrose acts as a protector of the cytoplasmic Membrane, or plasmalemma, against dehydration caused by freezing [66]. however, some authors concluded that using only sucrose for dehydration does not guarantee optimal cryopreservation, since in certain plant samples the water transfer Mechanism is slower or because complete dehydration could fatally alter the Metabolism of plant tissues [66-68]. Glycerol neutralizes osmotic stress due to its slower permeable effect on the cell Membrane compared to other cryoprotectants, allowing water to escape and partially dehydrate the cell $[58,69]$. This phenomenon occurs when the conditions of the extracellular environment are hypertonic, that is, the external concentration is greater than that existing inside the cell. For this reason, water inside the vacuole flows into the hypertonic Medium (osmosis) and the cell is dehydrated, reducing its size. Under suboptimal conditions, this event can cause the plasma Membrane to irreversibly separate from the cell wall. This phenomenon is called permanent plasmolysis and leads to cell necrosis as it cannot return to its normal state. Another type of plasmolysis, the incipient, refers to when the plant cell loses water but can return to its natural state [70]. This type of plasmolysis is essential to obtain when developing a cryopreservation protocol.

Despite the importance of loading treatment and induction of osmotolerance in plant cryopreservation, to ensure high survivability of explants, it is necessary to further treat samples with a plant vitrification solution (PVS), thus leading to vitrification [71].

Table 2. Composition of Most common loading solutions (LS).

\begin{tabular}{ccccc}
\hline \multirow{2}{*}{ Solution } & \multicolumn{3}{c}{ Component $(\%$ w/v) } & Reference \\
\cline { 2 - 5 } & DMSO & Glycerol & Sucrose & \\
\hline LS1 & - & 18.4 & 13.7 & {$[72]$} \\
\hline LS2 & 5.0 & 13.8 & 13.7 & [73] \\
\hline LS3 & 10.0 & 4.6 & 10.3 & \\
\hline LS4 & 10.0 & - & 24.0 & \\
\hline
\end{tabular}

\section{Plant Vitrification Solution}

PVS solutions are used in all Modern cryopreservation techniques due to the osmotic characteristics and protective effects Mentioned in the previous sections. PVS at low temperatures increases its viscosity, forming an amorphous glassy state, without ice formation [58]. There are Many variations of the PVS solution, of which the best known are PVS1 [74], PVS2 [75], PVS3 [72], and PVS4 [37,76]. The composition of each PVS is shown in Table 3. The solution comes into contact with the cell forming PVS solute compounds Modifying the glass transition temperature, and/or with the bound water, which prevents the formation of intercellular ice crystals [28,77]. 
Table 3. Composition of plant vitrification solutions (PVS).

\begin{tabular}{|c|c|c|c|c|c|c|c|}
\hline \multirow{2}{*}{ Solution } & \multicolumn{6}{|c|}{ Component $(\% w / v)$} & \multirow{2}{*}{ Reference } \\
\hline & Sorbitol & EG & DMSO & PEG & Glycerol & Sucrose & \\
\hline PVS1 & 9.1 & 15.0 & 7.0 & 15.0 & 22.0 & - & [74] \\
\hline PVS2 & - & 15.0 & 15.0 & - & 30.0 & 13.7 & [75] \\
\hline PVS3 & - & - & - & - & 50.0 & 50.0 & [72] \\
\hline PVS4 & - & 20.0 & - & - & 35.0 & 20.5 & [37] \\
\hline L-solution & - & 30.0 & 7.0 & - & 22.0 & 15.0 & [78] \\
\hline T-solution & - & 35.0 & 7.8 & 10.0 & - & - & [79] \\
\hline W-solution & 18.7 & - & 44.5 & - & - & - & [80] \\
\hline
\end{tabular}

DMSO is a common solvent in Most PVS: bipolar, water-soluble, and aprotic (it has no $\mathrm{O}-\mathrm{H}$ nor $\mathrm{N}-\mathrm{H}$ bonds, so it does not donate or receive protons). Its cryoprotective action is Mainly attributed to its ability to prevent the excessive accumulation of electrolytes and other substances during the cooling process. Moreover, its low Molecular weight allows rapid entry through the cell Membrane, in addition to Modulating the stability of the phospholipid bilayer. Electrostatic interactions of dMSO with phospholipids have been suggested, appearing to be critical for Membrane cryoprotection [81,82].

Ethylene glycol (EG) is widely used as a cryoprotectant, as it has a high coefficient of cell permeability. An important advantage of EG is that it prevents tissue superhydration after the rewarming of samples. Superhydration refers to the unwanted phenomenon of uncontrolled cell expansion after their inoculation on the Medium with lower osmoticum concentration, compared to the preculture Medium and PVS. This effect is usually observed if glycerol or dMSO are used. One should keep in mind that all treatments with EG Must be performed rapidly due to this compound being More toxic than glycerol [83].

Polyethylene glycol (PEG) is a polymer widely used in cryopreservation [84], being a non-penetrating cryoprotectant that, in addition to inhibiting the growth of ice crystals, prevents plant Material from suffering injuries caused by cold due to the increase in tonicity of PVS [85]. Evidence indicates that PEG works well in association with dMSO, increasing the percentage of viable explants [21] or with trehalose derivatives, which can adhere to PEG and Modify the thermodynamic events by replacing water on the surface of the plant's cell. It has been shown that short-chain PEGs are particularly effective in producing this effect [85].

\section{Modern CPAs}

Recently, nanosized liposomes from a complex of vegetable (soybean) and animal (egg yolk) phospholipids have been used as a cryoprotectant, being highly efficient in inducing tolerance to the thermal shock produced by storage in LN, especially in synergy with encapsulation in sodium alginate. Autoclaving did not demonstrate any influence on the cryoprotective efficiency of the liposome Mixture; however, it should be used fresh as long-term storage resulted in the loss of its beneficial properties [86].

Wheat proteins (such as WCS120, TaTIL, WCS19, and TaIRI-2), obtained from a crude wheat extract were successfully used to improve cryopreservation efficiency and could provide a promising alternative to dMSO [87]. Wang et al. [88] used fish antifreeze protein AFPI in cryopreservation of rice (Oryza sativa L.) embryogenic suspension cells. The positive or negative effect of AFP-I on the viability of cells during the vitrification Method depended on the concentration of AFP and their interaction with other CPAs.

Gold and zinc nanoparticles (NPs) are being studied as promising structures that can help protect animal [89] and human cells [90,91] during cryopreservation due to their small size and high thermal conductivity [92]. Nanoparticles can transport heat flux and cause thermal equilibrium with the environment within 10-200 ps [93]. Therefore, their 
application could significantly accelerate the thermodynamic events during the cooling and rewarming of plant Material and prevent the formation of lethal ice crystals. Some other research report NP addition into the culture Medium as an effective growth promoter during Micropropagation (see post-cryopreservation section). however, few studies are reporting the use of NPs as cryoprotective agents in plants. Montalbán et al. [94] used silver nanoparticles (AgNPs) in the culture Medium and the preservation solution for deepfreeze storage (at $-80^{\circ} \mathrm{C}$ ) of embryogenic cell lines of Pinus radiata d.Don with a recovery level above 75\%. Ren et al. [95] found that single-wall carbon nanotubes (SWCNTs) added to the PVS improve cell survival rate and reduce oxidative injury in cryopreserved embryogenic callus of Agapanthus praecox Willd. Kulus and Tymoszuk [96], on the other hand, reported that gold nanoparticles (AuNPs) added into the alginate bead Matrix improve the survivability of LN-recovered shoot tips of Lamprocapnos spectabilis (L.) Fukuhara by even $20 \%$. Future studies should focus on the utility of other nano-colloids, such as copper and titanium, in cryopreservation studies, particularly when added into the LS and PVS. Currently, at the UTP University of Science and Technology in Bydgoszcz, Poland, a research project is being conducted aiming to evaluate the usefulness and influence of silver and platinum nanoparticles, applied at various concentrations during different steps of a cryopreservation procedure, on the development and widely investigated stability of LN-derived plant Material (at the structural, Metabolic, (cyto)genetic, phenotypic, and biochemical levels).

\section{Cryopreservation Methods}

As stated previously, cryopreservation Methods can be classified according to the speed of cooling in protocols. Not only does the cooling rate affect the formation rate and size of intracellular and extracellular ice crystals, it also can impact solution effects that occur during the cryopreservation process. Rapid cooling minimizes solute concentration effects (because ice forms uniformly), but it Maximizes intracellular ice formation (as water does not have time to Migrate out of the cell). Slow cooling creates the opposite result by Maximizing water loss from the cell and minimizing intracellular ice formation, but it increases solution effects (www.thermofisher.com, access date 6 June 2021). The Most common Methods of rapid cooling-based cryopreservation are vitrification, encapsulationdehydration, encapsulation-vitrification, and droplet-vitrification (Figure 2).

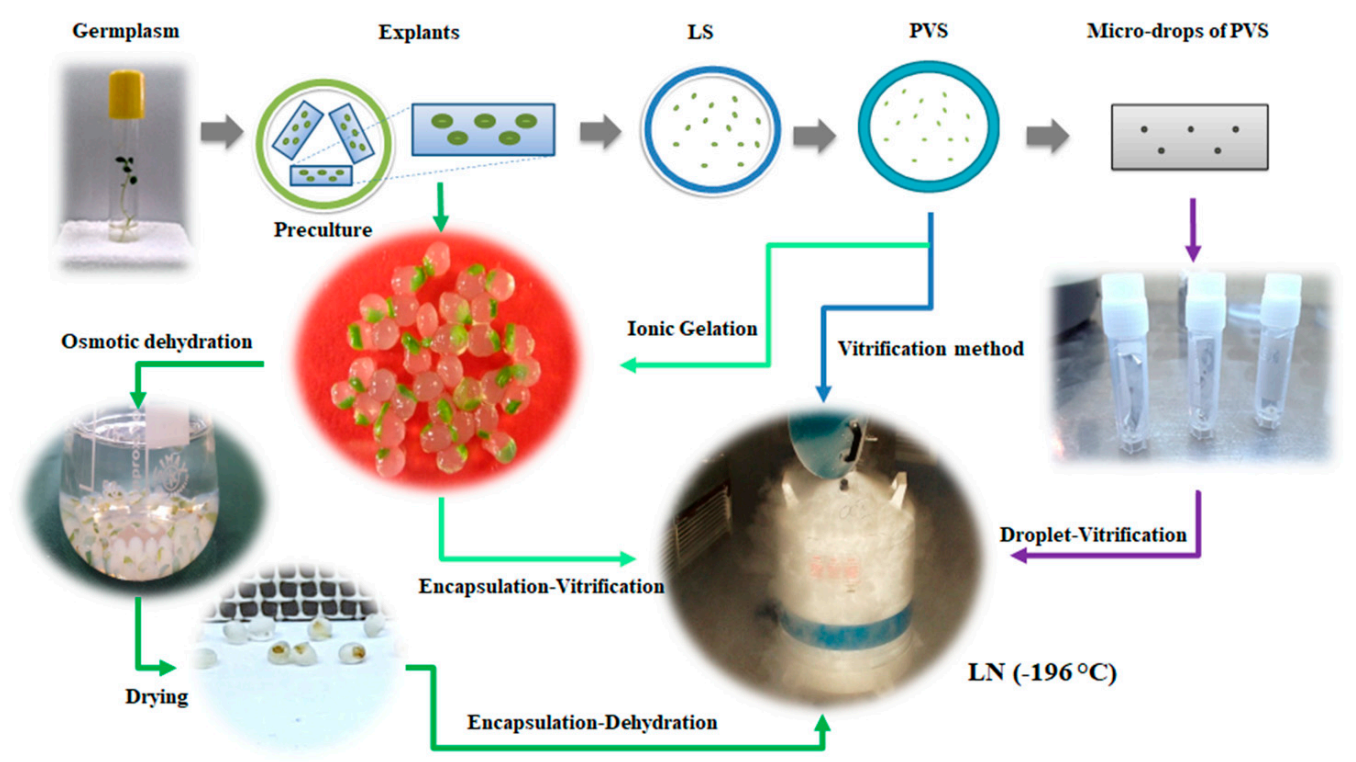

Figure 2. Most common Modern cryopreservation Methods. 


\subsection{Vitrification}

The first step is based on the explant treatment in a preculture Medium (PC), which usually contains salts from the MS Medium [97], a gelling agent (agar or phytagel), and sucrose at high concentration (usually $6-9 \% w / v$ ). Abscisic acid (ABA) and/or proline May also be added. The purpose of this step is to enhance antioxidant Metabolism and promote tolerance to stress, especially dehydration [98]. An additional cold-hardening step before or during preculture at $4{ }^{\circ} \mathrm{C}$ (or alternation of day/night temperature regimes) for 1-3 weeks May be effective for improving the post-thaw survival of some temperate and tropical species, e.g., potato $[99,100]$. The importance of this step was well demonstrated in kiwi (Actinidia chinensis Planch.), where shoot tips that were harvested from cold-hardened plantlets and pre-treated with sucrose and ascorbate showed $40 \%$ recovery against $0 \%$ in cryopreserved shoot tips that were not pre-treated [101].

The second stage consists of treating the samples with a loading solution (LS), usually for $20 \mathrm{~min}$. This step is followed by direct exposure to PVS, used in the third stage [98,102]. The duration of PVS treatment varies depending on the species, explant type, and PVS itself. PVS containing dMSO require a shorter use (20-40 $\mathrm{min}$ ) than those without it (even up to $180 \mathrm{~min}$ ) $[58,98]$. Finally, the dehydrated explants are placed in 2 ML cryovials and plunged in LN [102].

The first vitrification study was carried out in a particular orange cultivar native to Brazil, commonly known as 'laranja-umbigo' (Citrus sinensis Osb. var. Brasiliensis Tanaka). In the aforementioned study, the nucellar somatic cells were dehydrated in the PVS2 solution, using a simple Methodology with a short execution time (60\% PVS2 at $25^{\circ} \mathrm{C}$ for $5 \mathrm{~min}$, then chilled PVS2 at $0{ }^{\circ} \mathrm{C}$ for $3 \mathrm{~min}$ ), providing the regeneration level of up to $80 \%[28,75]$. This technique was applied to several other plant species of agronomic interest (Table 4).

\subsection{Encapsulation-Dehydration}

As some plant species do not withstand the harsh conditions of cryopreservation and PVS treatment, a Methodology was developed in which the explant follows an encapsulation process by ionic gelation. In this technique, an explant embedded in a drop of sodium alginate $(2-3 \% v / w)$, the Most studied encapsulating polymer, is placed with a pipet in a cationic solution, such as $100 \mathrm{~mm}$ calcium II chloride $\left(\mathrm{CaCl}_{2}\right)$, for approximately $30 \mathrm{~min}$ to form protective capsules for the explants. A carrier solution (glycerol and /or sucrose) is also usually added to sodium alginate. These encapsulated explants are dehydrated-osmotically in a series of sucrose solutions (with increasing concentration; up to even $1.0 \mathrm{M}$ ), and physically with silica gel or in a laminar flow chamber (to a final level of $10-30 \%$ of the initial Moisture content)—before immersion in LN $[83,103]$.

\subsection{Encapsulation-Vitrification}

This is a Method that combines elements of vitrification and encapsulation-dehydration techniques. The alginate beads are loaded with a sucrose-glycerol solution, dehydrated with PVS, and immersed directly in LN. For rewarming, the capsules are quickly rewarmed in a water bath. The PVS solution is removed from the capsules by washing with sucrose solution and then placed in MS Medium for explant recovery $[83,104]$. In contrast to the encapsulation-dehydration Method, dehydration with PVS is faster and easier to control than drying in laminar flow or with silica gel [102].

\subsection{Droplet-Vitrification}

The droplet-vitrification is a Modified vitrification technique, which Means that the first stages (preculture, LS and PVS treatments) are identical as described in the Vitrification Method section. What sets the Methods apart is the cooling and rewarming Mode of the explant. In the droplet Method, cooling is performed in an ultra-fast Manner, where the explant trapped in a Micro-drop (3-6 $\mu \mathrm{L}$ ) of PVS solution is placed on aluminum sheets to be immersed directly in LN. In this process, a thermal drop of up to $1000{ }^{\circ} \mathrm{C} \mathrm{min}^{-1}$ 
occurs. On the other hand, during rewarming, foil strips with explants are placed in a sucrose solution and left at room temperature for about 20-30 min, favoring devitrification. Thus, the damage caused by the crystallization of the solution is minimized without compromising the viability of the cells. The Main interest of this Method is the possibility of achieving very high rates of cooling and/or rewarming due to the low volume of cryoprotectant Medium in which the explants are placed and the favorable thermal conductivity of aluminum $[44,58]$.

\subsection{Cryo-Plate Techniques}

The cryo-plates techniques were developed by Yamamoto et al. [105] and Niino et al. [106], who adapted the Modified vitrification Method to provide stability and greater tolerance of the explant to sudden changes in temperature. The concept of the techniques is based on aluminum Microplates containing several oval wells. The explants attached to the cryo-plates with alginate solution are then dehydrated. The V-cryo-plate is based on PVS dehydration, while the d-cryo-plate Method is based on air dehydration in the laminar flow chamber for a controlled time. The techniques facilitate the handling of cryopreservation and rewarming procedures and minimize the risk of tiny explants loss and their Mechanical injury [107-109].

\subsection{Vacuum-Infiltration-Vitrification}

The vacuum-infiltration-vitrification (VIV) technique was developed by Nadarajan and Pritchard [110]. The use of a vacuum during explant incubation in a CPA allows for its increased penetration, and therefore reduces the total duration of the protocol. Another advantage of this approach is the reduction of temperature dependency for cryoprotectant application. VIV cryopreservation also overcomes the problem of specimen heterogeneity (mass, volume, oil composition, and thermal properties). Nonetheless, the technique is rarely used.

\subsection{Post-Cryopreservation}

Post-cryopreservation treatments are equally as important as the pre-cooling steps to obtain satisfying (at least 40\%) explant recovery after cryostorage. Rewarming is performed either at room temperature (as in the case of droplet-vitrification technique) or quickly in a $35-40{ }^{\circ} \mathrm{C}$ water bath to avoid ice recrystallization (aggregation of smaller crystals into bigger ones).

PVS are highly effective when performing dehydration or binding to water, preventing it from crystallizing; however, some components of these solutions are toxic to the cell (e.g., dMSO). Consequently, it is necessary to completely remove the PVS solution from the Biological Material and to secure the cells against uncontrolled rehydration after LN storage [111]. Therefore, after rewarming, the explants are washed with a concentrated sucrose solution, usually liquid MS salts with $1.2 \mathrm{M}$ sucrose for $2 \times 1.5 \mathrm{~min}$, the so-called Sakai's unloading solution (RS) [28]. Maintaining the temperature of the cells at $0{ }^{\circ} \mathrm{C}$ during the de- and rehydration processes increased cell survival in wheat [49].

The selection of an appropriate recovery Medium plays a critical role in plant regrowth by controlling totipotency, growth, and development of cells and tissues. It is recommended to perform the recovery culture of non-encapsulated explants on a Medium with increased osmotic potential and with an addition of appropriate plant growth regulators (PGRs), such as gibberellic acid (GA) during the first few days of recovery [112]. Recent studies demonstrated a higher efficiency of meta-topolin $(m \mathrm{~T})$, a non-conventional cytokinin, than $\mathrm{N}^{6}$-benzyladenine (BA) when used during the recovery phase in the LNderived lateral buds of hazelnut (Corylus avellana L.) [113]. Conventional cytokinins, such as BA, are reported to cause certain Morpho-physiological, anatomical, and biochemical disorders [114,115]. Meta-topolin varies from BA in the conversion of its Major Metabolic product O-glucoside, which translocates quickly to different parts of the explants [116]. By 
such Means, $m \mathrm{~T}$ alleviates in vitro-influenced disorders such as leaf senescence, hyperhydric shoots, and shoot apex and leaf necrosis $[115,117,118]$.

Physical conditions in the growth room should also be considered. Light quantity and quality (i.e., its intensity, photoperiod, and spectral composition) affect Morphogenetic responses of in vitro plants. Modification of light spectra both before LN storage and during recovery after cryopreservation improves survival and recovery. Yoon et al. [45] reported that several potato cultivars grown under high light intensity $\left(140 \mathrm{nmol} \mathrm{M}^{-2} \mathrm{~s}^{-1}\right)$ prior to cryopreservation resulted in significantly higher post-cryopreservation recovery. Edesi et al. [119] showed that blue light promoted growth potential, photomorphogenesis, and subsequent survival after cryopreservation of potato clones, while Mølmann et al. [120] showed that the red light produced strong inhibition of sprout elongation even at low irradiances 10-100 $\mathrm{nmol} \mathrm{M}^{-2} \mathrm{~s}^{-1}$ in the same species. Nonetheless, the effect of Modified light conditions on cryopreservation efficiency is still not well studied.

Successful recovery appears to be dependent upon the presence of antioxidant protection from reactive oxygen species (ROS), often occurring after cryostorage [121]. The addition of vitamin additives into the culture Medium such as ascorbic acid and tocopherol were shown to reduce oxidative damage. Moreover, the use of non-vitamin antioxidants (antiradicals) such as lipoic acid, glutathione, glycine betaine, and polyvinylpyrrolidone is beneficial. These natural compounds showed interesting results for viability in Rubus spp. shoot tips, which increased by $25 \%$ after LN storage [122].

The use of NPs in recent years has received attention since they are proving benefits to improve in vitro plant properties and regeneration rate, depending on their type, size, shape, and concentration $[123,124]$. It is presumed that the addition of NPs into the recovery Medium could result in pores formation in the roots stimulating a greater uptake of water and, consequently, in significant plant growth. This phenomenon appeared in the case of Manganese nanoparticles (MnNPs), which produced a differential change in the Morphology and physiology of deadly nightshade (Atropa belladonna L.) with lower doses at $50 \mathrm{Mg} \cdot \mathrm{L}^{-1}$ [125]. Silver nanoparticles (AgNPs) were applied to rice (Oryza sativa L., cv. Swarna) and described as phytostimulants in some active compounds (i.e., chlorophyll and carotenoids) without negative impacts on the plant [126]. On the other hand, the NP excess could produce phytotoxicity, oxidative stress damage, and genotoxic effects $[125,127]$. For example, growth inhibition, especially in the root zone, was evident in wheat (Triticum aestivum L.) using copper nanoparticles (CuNPs) [128]. Overall, nanoparticles have become an attractive alternative to improve agrobiotechnological production; even so, there are still limitations that Must be studied, analyzed, and controlled to successfully apply NPs during the pre- and post-LN storage steps.

\section{Cryopreservation Applications of Agronomic Interest}

Most studies related to cryopreservation are published with a protocol applicable for individual species and varieties or cultivars, as in the case of beetroot (Beta vulgaris L.) [129], ginger (Zingiber officinale Rosc.) [130], oca (Oxalis tuberosa Mol.) [131], or ulluco (Ullucus tuberosus Cal) [132], without Maintaining a standard protocol for a large group, such as grains, fruits, and vegetables. however, a study published in 2017 was essential to adapt a basic protocol for the cryopreservation of a More diverse group of crops in the agronomic sector [133]. In this study, the shoot tips of four genera (Malus, Solanum, Lonicera, and Berberis) were tested with variations of cold acclimation, preculture Media, and PVS2 exposure times. The use of the simple vitrification Method based on a $0.3 \mathrm{M}$ sucrose pretreatment and 30- (for potato) or 80-minute exposure to PVS2 (for apple and berry) showed a Mean viability greater than $50 \%$. This could greatly reduce some other unnecessary Materials for use in cryopreservation banks.

Another successful protocol that has been used is encapsulation-dehydration with the use of LS composed of $0.8 \mathrm{M}$ sucrose and $0.1 \mathrm{M}$ glycerol (10-20 min exposure) and drying over a silica gel for 14 to $21 \mathrm{~h}$. This protocol was applied to seeds of lettuce, Chinese kale, and 'pak choi' (a type of Chinese cabbage), which had a survival rate of $100 \%$, 
being a great advance for the use of standard protocols useful in cryogenic banks. Two other vegetables, 'Chinese cabbage' and 'White cabbage' in bloom, were also studied and had a survival rate of $60-90.9 \%$ and $25-91.6 \%$, respectively, and were able to grow in the ex vitro field conditions [134]. The same cryopreservation Method was successfully used for in vitro-derived shoot apices of mint (Mentha $\times$ piperita L.) [103]. The use of PVS2 and PVS3 in cryopreservation of mint germplasm also showed suitable results of viability. however, some accessions, such as $M$. requienii and $M$. villosanervata, did not have an as good response with PVS2, highlighting the use of PVS3 in this plant genera for complete recovery of specimens [135].

The chili pepper seeds (Huareo ${ }^{\circ} 13$ ) were cryopreserved with the vitrification Method, by immersing them in an LS (composed of $0.4 \mathrm{M}$ sucrose and $2.0 \mathrm{M}$ glycerol) and in PVS2, applied for different durations ( 0,10 , and $20 \mathrm{~min} ; 0,30$, and $60 \mathrm{~min}$, respectively), showing a survival rate of $100 \%$. These in vitro seedlings were successfully transplanted to field conditions [136].

Plants grown from seeds of corn (Zea Mays L.) did not show a significant difference compared to those obtained from seeds previously stored in cryopreserved germplasm banks. The germination after LN storage was almost total and complete. Thus, a cryobank of Maize landraces from two regions of Costa Rica was established [137,138].

One of the largest agronomic economies is Managed by the winemaking sector. The Maintenance and in vitro cultivation of grapevine (Vitis spp.) is highly expensive due to the specific growth requirements. Therefore, a cryopreservation protocol of this fruit crop was developed. Apical shoot tips (1 mm long) were pre-treated for three days on MS Medium containing 0.3 M sucrose, salicylic acid (SA), glutathione, ascorbic acid, and plant preservative Mixture. half-strength PVS2 was applied for $30 \mathrm{~min}$ at $22^{\circ} \mathrm{C}$, prior to full-strength PVS2 treatment at $0{ }^{\circ} \mathrm{C}$ for another $30 \mathrm{~min}$. This procedure achieved high levels of regrowth (55\%) in V. vinifera 'Chardonnay' and 'Riesling', as well as V. hybrid 'Oppenheim'. Based on the histological observations, it can be deduced that this positive response was related to the use of apical tips with Multiple lateral Meristems that survived LN immersion [139].

Onions are another important food source in global agronomic production, for which cryopreservation protocols have been developed. One of them was based on the dropletvitrification Method, applied for shallots (Allium cepa 'Aggregatum'). Maintenance of in vitro cultures was performed in MS Medium supplemented with PGRs, such as BA and 1-naphthaleneacetic acid (NAA). For cryopreservation, shoot tips were precultured with $0.3-0.5 \mathrm{M}$ sucrose for 1 day followed by a loading phase in LS (composed of $0.6 \mathrm{M}$ sucrose and $2.0 \mathrm{M}$ glycerol) and dehydration in PVS3 (20 min and $3 \mathrm{~h}$ ). This approach produced a $94 \%$ survival rate and 58\% recovery rate. The cryopreservation-derived plant Material showed no significant genetic difference from the non-cryopreserved control, nor changes in the content of components such as sugars and flavonoids $[47,140]$. In the 'Kverve' and 'Lunteviga' cultivars, the same steps of the droplet-vitrification Method were applied. As a result, regrowth of $45 \%$ and $70 \%$ explants was observed. Both studies concluded that with onion, better results are obtained with explants treated with PVS3 than with PVS2, as the former one is less toxic to cells and provided a broader safe temperature range $\left(-196{ }^{\circ} \mathrm{C}\right.$ to $\left.-88^{\circ} \mathrm{C}\right)$, compared to that $\left(-196^{\circ} \mathrm{C}\right.$ to $\left.-116^{\circ} \mathrm{C}\right)$ of PVS2 $[47,141]$.

As for garlic (Allium sativum L.), the efficiency of cryopreservation depends on the origin of the donor explant. According to Keller [142], in vitro-grown Material is the least responsive one concerning the regrowth rates. however, post-harvest storage duration of bulbs dramatically influences survival and recovery levels of cryopreserved shoot tips, which were nil for samples cryopreserved immediately after harvest and highest after 3 and 6 Months of storage [38]. The field performance of LN-recovered garlic plantlets under ex vitro conditions was compared with garlic derived from the field, evaluating parameters such as net photosynthetic rate, bulb characteristics, and efficiency of eradication of yellow onion dwarf virus (OYDV) induced by cryotherapy. The superiority of the Morphological traits of cryopreservation-derived garlic was evident, with greater size and weight of bulbs, 
in addition to a virus elimination rate of $75 \%$. These results are relevant for the future application of cryopreservation to obtain products of better quality for the agronomic sector [141]. According to Kim et al. [143], the use of PVS3 is the Most appropriate for the cryopreservation of garlic. Vitrification of seven garlic cultivars with PVS3 for 150-180 min ensured $92 \%$ recovery after rewarming [38]. The droplet-vitrification Method was also successfully applied with several Allium germplasm collections, indicating that it can be used on a large scale to carry out international exchanges and with great agronomic potential $[45,144]$. On the other hand, the use of physical/air dehydration in this species has been shown to be harmful, as it radically decreases cryopreservation success. In parallel, it was shown that the addition of PGRs into the recovery Medium, such as zeatin (ZEA) and gibberellic acid (GA), would significantly increase the final fresh weight of the LNrecovered plantlets [38].

The potato is thoroughly studied as one of the Main agronomic crops in the world [145]. There are over 4000 varieties and cultivars of this species developed over time by breeding programs. Moreover, depending on the area of cultivation, the species has developed genetic diversity through adaptation to different (a)biotic conditions [39]. To preserve this genetic variability, it is necessary to Make use of vitrification-based cryopreservation Methods.

The effect of the subculture conditions of the Mother plant of cryopreserved potato ('Dejima', cultivated; 'STN13', wild) was studied by Yoon et al. [45] using the dropletvitrification Method. It was observed that the studied conditions such as light intensity, aeration, and planting density significantly affected the survival of the cryopreserved and non-cryopreserved shoot tips, in both genotypes. Combinations of high light intensity, ventilation of culture vessels, and low planting density enhanced the viability of cryopreserved shoot tips (over 70\%), with aeration being the Most critical factor. The duration of the subculture and the location of the explant on the Microshoot had a significant effect on the cryopreservation efficiency. The ideal duration of the subculture was 7 and 5 weeks and the optimal shoot tip size was 1.5 to $2.0 \mathrm{~mm}$ and 1.0 to $1.5 \mathrm{~mm}$ for 'Dejima' and 'STN13', respectively. The highest and lowest survival rates were found in explants sampled from the Middle and apex parts of Mother plants, respectively, in both cultivars studied. The survival of cryopreserved explants was influenced by the concentration of sucrose in the PC Medium and the duration of the PC. The highest survival of cryopreserved shoot tips (91.9\% for 'Dejima' and $86.4 \%$ for 'STN13') was observed when PC with $0.3 \mathrm{M}$ sucrose for $8 \mathrm{~h}$ was followed by $0.7 \mathrm{M}$ sucrose for $18 \mathrm{~h}$ and with PVS2 treatment for $20 \mathrm{~min}$. These results indicate that the parameters of the subculture of the Mother plant and the preculture of the explants Must be carefully optimized, especially in the case of wild varieties.

The 'Criolla' potato (Solanum tuberosum Group Phreja) was studied through the encapsulation-dehydration Method, using calcium alginate as an encapsulating Matrix and silica gel for desiccation [146]. In this study, the effect of various sugars added into the PC Medium was evaluated. The highest regrowth rates of $88 \%$ and $91 \%$ were reported when Maltose and trehalose were applied, respectively, indicating those compounds as the Most effective cryoprotectants. The viability of potato shoot tips in the presence of polyols was very low and no recovery was obtained after cooling of explants that were precultured in Monosaccharides. The authors also demonstrated a significant effect of PC Medium composition on the total soluble carbohydrate content in the cells. Another study was performed with the 'Climax', 'Avon', and 'Ceza', in which a direct relationship was obtained between the concentration of sucrose and the time in the PC Medium to achieve higher viability [147].

The first purple-fleshed potato cryopreservation experiment by Li et al. [104] was using the encapsulation-vitrification and the droplet-vitrification Methods. The duration of PVS2 dehydration influenced the survival rate, being the highest after 5-7 h and $6 \mathrm{~h}$ treatment for 'E03-2677' and for 'Blue Congo' cultivars, respectively, in the encapsulationvitrification technique, and 30-50 $\mathrm{min}$ and $40 \mathrm{~min}$, respectively, in droplet-vitrification. Vegetative growth in regenerated shoots after three weeks of post-rewarming culture 
was significantly lower than that of the control, but Markedly increased in the following six Months of culture.

Studies on Solanum juzecpzukii 'Piñaza', a species tolerant to low temperatures, and Solanum tuberosum spp. andígena 'Ccompis' and S. tuberosum 'Désirée', which are droughttolerant, gave a positive response to the use of the droplet-vitrification Method. The following parameters were selected as optimal: explants at three weeks of age were exposed for $15 \mathrm{~min}$ to LS and $50 \mathrm{~min}$ to PVS2. This Method showed a significantly higher recovery than the original IPC cryobank Method (20 min in PVS2) [44]. In parallel, Solanum tuberosum was studied using $10 \% \mathrm{dMSO}$ as a cryoprotectant, obtaining a Mean survival rate of $72 \%$, in addition to an average recovery rate of $48 \%$ [148].

Potato viruses can cause significant problems in field cultivation. Among them, potato virus $S$ is one of the Most difficult pathogens to eliminate in agricultural practice. Cryotreatment can be an effective tool in eradicating viruses from vegetatively propagated species. Kushnarenko et al. [149] described the effect of combined ribavirin treatment and cryotherapy for efficient eradication of five potato viruses (potato leaf virus, potato $\mathrm{M}$, S, X, and Y viruses). Ruiz-Sáenz et al. [5] studied the effect of SA as a pre-treatment in the cryotherapy of seedling clones of $S$. tuberosum 'Désirée', which are drought-tolerant, gave a positive response to the use of the droplet-vitrification Method. The following parameters were selected as optimal: explants at three weeks of age were exposed for $15 \mathrm{~min}$ to LS and $50 \mathrm{~min}$ to PVS2. This Method showed a significantly higher recovery than the original IPC cryobank Method (20 min in PVS2) [44]. In parallel, Solanum tuberosum, and the Method will be adapted to other potato cultivars prone to contagion. Moreover, AyalaHernandez et al. [150] demonstrated that SA induces stress tolerance to which explants are subjected during cryopreservation. Pretreatment with $10^{-6}$ and $10^{-5} \mathrm{M} \mathrm{SA}$ provided significantly greater survival of explants to cryogenics (2.17-3.21 times with respect to the control).

Some recently developed cryoprotocols applicable to various plant species are shown in Table 4, indicating the droplet-vitrification Method as the Most common one with agronomic plants, and the Solanum genus as the Most well-studied in terms of longterm storage.

Table 4. Recently developed cryopreservation protocols of selected crops of agronomic interest.

\begin{tabular}{|c|c|c|c|c|c|c|c|c|}
\hline $\begin{array}{c}\text { Biological } \\
\text { Material }\end{array}$ & Explant & Preculture & Pretreatment & $\begin{array}{l}\text { Storage and } \\
\text { Rewarming }\end{array}$ & Recovery & $\begin{array}{l}\mathrm{S}(\mathrm{R}) \\
(\%)\end{array}$ & Remarks & Ref. \\
\hline \multicolumn{9}{|c|}{ Vitrification } \\
\hline $\begin{array}{l}\text { Allium cepa } \\
\text { var. } \\
\text { aggregatum } \\
\text { (Shallot } \\
\text { '10603') }\end{array}$ & $\begin{array}{c}\text { Shoot tips } \\
(2-3 \mathrm{~mm}) \\
\text { with } 4-5 \\
\text { leaf } \\
\text { primordia }\end{array}$ & $\begin{array}{c}\text { MS Medium } \\
+30 \mathrm{~g} / \mathrm{L} \\
\text { sucrose, } \\
0.5 \mathrm{mg} / \mathrm{L} \mathrm{BA}, \\
0.1 \mathrm{mg} / \mathrm{L} \\
\text { NAA and } \\
8 \mathrm{~g} / \mathrm{L} \text { agar } \\
\text { (pH, 5.8) }\end{array}$ & $\begin{array}{c}\text { PVS3 at } \\
24^{\circ} \mathrm{C} \text { for } 3 \mathrm{~h}\end{array}$ & $\begin{array}{l}\text { LN storage } \\
\text { for } 1 \mathrm{~h}\end{array}$ & $\begin{array}{l}\text { Preculture } \\
\text { Medium for } \\
8 \text { weeks }\end{array}$ & $>95$ & $\begin{array}{l}\text { Rooting, } \\
\text { vegetative } \\
\text { growth, bulb } \\
\text { production, } \\
\text { genetic } \\
\text { stability, and } \\
\text { biochemical } \\
\text { compounds } \\
\text { were Main- } \\
\text { tained after LN } \\
\text { storage. }\end{array}$ & [151] \\
\hline
\end{tabular}


Table 4. Cont.

\begin{tabular}{|c|c|c|c|c|c|c|c|c|}
\hline $\begin{array}{c}\text { Biological } \\
\text { Material }\end{array}$ & Explant & Preculture & Pretreatment & $\begin{array}{l}\text { Storage and } \\
\text { Rewarming }\end{array}$ & Recovery & $\begin{array}{l}\mathrm{S}(\mathrm{R}) \\
(\%)\end{array}$ & Remarks & Ref. \\
\hline $\begin{array}{l}\text { Allium } \\
\text { sativum } \\
\text { 'Gailiang- } \\
\text { suan' cv. } \\
\text { G064 }\end{array}$ & $\begin{array}{l}\text { Shoot } \\
\text { apices } \\
(2 \mathrm{~mm})\end{array}$ & $\begin{array}{l}\text { MS Medium } \\
\text { with } 6.5 \mathrm{~g} / \mathrm{L} \\
\text { agar and } \\
0.5 \mathrm{M} \text { sucrose } \\
\text { for } 4 \mathrm{~d} \text { at } \\
23^{\circ} \mathrm{C} \text { and } \\
12 \mathrm{~h} \\
\text { photoperiod }\end{array}$ & $\begin{array}{c}\text { LS: } 18.4 \% \\
\text { glycerol }+ \\
20.5 \% \\
\text { sucrose } \\
\text { in MS } \\
\text { Medium } \\
\text { without agar } \\
\text { for } 20 \text { min at } \\
24{ }^{\circ} \mathrm{C} \text {. } \\
\text { PVS2 for } \\
30 \text { min at } \\
0{ }^{\circ} \mathrm{C}\end{array}$ & $\begin{array}{l}\text { LN storage } \\
\text { for } 1 \mathrm{~h} \text {. Rapid } \\
\text { rewarming } \\
\text { by directly } \\
\text { plunging the } \\
\text { samples into } \\
\text { RS for } 10 \text { min } \\
\text { at RT }\end{array}$ & $\begin{array}{c}\mathrm{B} 5+ \\
0.1 \mathrm{mg} / \mathrm{L} \\
\mathrm{NAA}+ \\
2.0 \mathrm{mg} / \mathrm{L} \\
6-\mathrm{BA}, \text { with } \\
30 \mathrm{~g} / \mathrm{L} \\
\text { sucrose, } \\
6.5 \mathrm{~g} / \mathrm{L} \text { agar } \\
\text { in the dark } \\
\text { for } 4 \mathrm{~d}\end{array}$ & $\begin{array}{c}82.6 \\
(75.9)\end{array}$ & $\begin{array}{c}\text { The } \\
\text { LN-recovered } \\
\text { plants were } \\
\text { stable at the } \\
\text { genetic and } \\
\text { structural } \\
\text { levels. }\end{array}$ & [152] \\
\hline $\begin{array}{l}\text { Solanum } \\
\text { tuberosum } \\
\text { 'Superior' }\end{array}$ & $\begin{array}{l}\text { Shoot tips } \\
(2-3 \mathrm{~mm})\end{array}$ & $\begin{array}{c}\text { Liquid MS } \\
\text { Medium } \\
\text { with } 0.3 \mathrm{M} \\
\text { sucrose on a } \\
\text { rotary shaker } \\
\text { at } 60 \mathrm{rpm} \text { for } \\
24 \mathrm{~h}\end{array}$ & $\begin{array}{c}\text { LS: AFP III, } \\
(0-2000 \\
\text { ng/mL) }+ \\
\text { liquid MS } \\
\text { Medium, } \\
0.6 \mathrm{M} \\
\text { sucrose, } \\
2.0 \mathrm{M} \\
\text { glycerol at } \\
25^{\circ} \mathrm{C} \text { for } \\
1.5 \mathrm{~h} \text {. } \\
\text { Or PVS2 with } \\
\text { AFP III for } \\
30 \text { min at } \\
25^{\circ} \mathrm{C}\end{array}$ & $\begin{array}{l}\text { LN storage } \\
\text { for } 30 \text { min in } \\
\text { and at } \\
-20{ }^{\circ} \mathrm{C} \text { for } \\
1 \mathrm{~h} \text {. } \\
\text { Rewarmed in } \\
\text { a water bath } \\
\left(38^{\circ} \mathrm{C}\right) \text { for } \\
2 \text { min, and } \\
\text { washed for } \\
20 \text { min in } \\
\mathrm{NH}_{4}^{+}- \\
\text {free MS } \\
\text { Medium } \\
\text { with } 1.2 \mathrm{M} \\
\text { sucrose at } \\
25^{\circ} \mathrm{C}\end{array}$ & $\begin{array}{l}\text { MS Medium } \\
\text { with } 88 \mathrm{~mm} \\
\text { sucrose, agar } \\
\quad 8 \mathrm{~g} / \mathrm{L}\end{array}$ & $\begin{array}{c}26-39 \\
(12-30)\end{array}$ & $\begin{array}{l}\text { This finding } \\
\text { suggests that } \\
\text { AFP increased } \\
\text { cryopreserva- } \\
\text { tion efficiency } \\
\text { by } \\
\text { transcriptional } \\
\text { regulation of } \\
\text { these genes, } \\
\text { which Might } \\
\text { protect plant } \\
\text { cell Mem- } \\
\text { branes from } \\
\text { cold } \\
\text { stress during } \\
\text { cryopreserva- } \\
\text { tion. }\end{array}$ & [153] \\
\hline $\begin{array}{c}\text { Solanum } \\
\text { tuberosum } \\
\quad(28 \\
\text { genotypes) }\end{array}$ & $\begin{array}{c}\text { Apical } \\
\text { shoots } \\
(2-3 \mathrm{~mm})\end{array}$ & $\begin{array}{l}\text { 16-20 h in } \\
\text { liquid MS } \\
\text { Medium } \\
\text { with } 0.09 \mathrm{M} \\
\text { sucrose }\end{array}$ & $\begin{array}{l}\text { liquid MS } \\
\text { Medium } \\
\text { with } 0.09 \mathrm{M} \\
\text { sucrose and } \\
10 \% \text { dMSO } \\
\text { for } 2 \mathrm{~h} \text { at RT }\end{array}$ & $\begin{array}{l}\text { LN storage } \\
\text { for } 1 \mathrm{~h} \text {. } \\
\text { Rewarming } \\
\text { in a water } \\
\text { bath at } 40{ }^{\circ} \mathrm{C}\end{array}$ & $\begin{array}{c}\text { MS Medium } \\
\text { with } 0.09 \mathrm{M} \\
\text { sucrose, } \\
0.5 \mathrm{mg} / \mathrm{L} \mathrm{ZR} \text {, } \\
0.2 \mathrm{mg} / \mathrm{L} \mathrm{GA} \text {, } \\
0.5 \mathrm{mg} / \mathrm{L} \\
\mathrm{IAA} \text { at } \\
25 / 20^{\circ} \mathrm{C}- \\
\mathrm{d} / \mathrm{n} \\
\text { temperature } \\
16 \mathrm{~h} \\
\text { photoperiod } \\
\text { at low light } \\
\text { intensity }\end{array}$ & (54) & $\begin{array}{l}\text { All } 28 \text { geno- } \\
\text { types had higher } \\
\text { regrowth after } \\
\text { cryopreserva- } \\
\text { tion using } \\
\text { PVS3 instead } \\
\text { of dMSO. }\end{array}$ & [154] \\
\hline $\begin{array}{c}\text { S. } \\
\text { tuberosum } \\
\text { 'Zihuabai' }\end{array}$ & $\begin{array}{l}\text { Nodal } \\
\text { segments } \\
(1 \mathrm{~cm})\end{array}$ & $\begin{array}{l}\text { MS with } \\
0.45 \mathrm{M} \\
\text { sucrose in } \\
\text { the dark at } \\
5^{\circ} \mathrm{C} \text { for } 1 \mathrm{~d}\end{array}$ & $\begin{array}{c}60-80 \% \text { PVS2 } \\
\text { for } 30 \mathrm{~min} \\
\text { and } 100 \% \\
\text { PVS2 for } \\
40 \mathrm{~min} \text { at } \\
0{ }^{\circ} \mathrm{C}\end{array}$ & $\begin{array}{l}\text { LN storage } \\
\text { for } 1 \mathrm{~h} \text {. } \\
\text { Rewarming } \\
\text { in a water } \\
\text { bath at } 38^{\circ} \mathrm{C} \\
\text { for } 2 \text { min and } \\
\text { then in RS at } \\
25^{\circ} \mathrm{C} \text { for } \\
20 \mathrm{~min}\end{array}$ & $\begin{array}{c}\text { MS with } \\
0.5 \mathrm{mg} / \mathrm{L} \\
\text { IAA, } \\
0.5 \mathrm{mg} / \mathrm{L} \mathrm{ZR} \\
\text { and } 0.2 \mathrm{mg} / \mathrm{L} \\
\mathrm{GA} \text { and kept } \\
\text { in the dark at } \\
22 \pm 2{ }^{\circ} \mathrm{C} \text { for } \\
3 \mathrm{~d}\end{array}$ & $\begin{array}{c}\sim 80 \\
(45.5)\end{array}$ & $\begin{array}{l}\text { No genetic } \\
\text { alterations } \\
\text { were detected } \\
\text { in the } \\
\text { recovered } \\
\text { shoots by ISSR } \\
\text { and AFLP. }\end{array}$ & [39] \\
\hline
\end{tabular}


Table 4. Cont.

\begin{tabular}{|c|c|c|c|c|c|c|c|c|}
\hline $\begin{array}{c}\text { Biological } \\
\text { Material }\end{array}$ & Explant & Preculture & Pretreatment & $\begin{array}{l}\text { Storage and } \\
\text { Rewarming }\end{array}$ & Recovery & $\begin{array}{l}S(R) \\
(\%)\end{array}$ & Remarks & Ref. \\
\hline $\begin{array}{l}\text { Vitis } \\
\text { vinifera L. } \\
\text { 'Flame } \\
\text { Seedless' }\end{array}$ & $\begin{array}{l}\text { Axillary } \\
\text { buds }\end{array}$ & MS Medium & $\begin{array}{c}\text { PVS2 at } \\
25^{\circ} \mathrm{C} \text { with } \\
\text { agitation for } \\
3 \mathrm{~h}\end{array}$ & $\begin{array}{c}\text { LN storage } \\
\text { for } \\
1 \mathrm{~h}, 1 \text { week, } \\
\text { and } 1 \text { Month. } \\
\text { Rewarming } \\
\text { in } \\
\text { a water bath } \\
\text { at } 38^{\circ} \mathrm{C} \text { for } \\
3 \text { min }\end{array}$ & NR & NR & $\begin{array}{l}\text { Cryopreservation } \\
\text { affect genetic } \\
\text { stability in } \\
\text { grapevine, } \\
\text { regardless of } \\
\text { storage dura- } \\
\text { tion. }\end{array}$ & [155] \\
\hline \multicolumn{9}{|c|}{ Droplet-Vitrification } \\
\hline $\begin{array}{l}\text { Allium cepa } \\
\text { 'Kverve' } \\
\text { 'Lunteviga' }\end{array}$ & $\begin{array}{l}\text { Shoot tips } \\
(2-3 \mathrm{~mm}) \text {, } \\
4 \text { weeks old }\end{array}$ & $\begin{array}{c}\text { MS Medium } \\
\text { with } 0.3 \mathrm{M} \\
\text { and } 0.5 \mathrm{M} \\
\text { sucrose, } \\
1 \mathrm{~d} \text { each }\end{array}$ & $\begin{array}{c}\text { LS: } 2.0 \mathrm{M} \\
\text { glycerol }+ \\
0.6 \mathrm{M} \text { sucrose } \\
(20 \mathrm{~min}) \text { and } \\
\text { PVS3 at } \\
24^{\circ} \mathrm{C}(3 \mathrm{~h})\end{array}$ & $\begin{array}{l}\text { LN storage } \\
\text { for } 1 \mathrm{~h} \text {. } \\
\text { Rewarming } \\
\text { in RS at } 25^{\circ} \mathrm{C} \\
\text { for } 20 \mathrm{~min}\end{array}$ & $\begin{array}{l}\text { MS Medium } \\
\text { with } 0.3 \mathrm{M} \\
\text { sucrose for } \\
2 \mathrm{~d} \text { in the } \\
\text { dark and } \\
\text { then } \\
\text { transferred to } \\
\text { light }\end{array}$ & $(45-70)$ & $\begin{array}{l}\text { PVS2 } \\
\text { was More } \\
\text { effective than } \\
\text { PVS2 in } \\
\text { securing the } \\
\text { explants. Cry- } \\
\text { opreservation } \\
\text { of shoot tips } \\
\text { was More } \\
\text { effective than } \\
\text { of Meriste- } \\
\text { moids. }\end{array}$ & [140] \\
\hline $\begin{array}{l}\text { Allium cepa } \\
\text { var. } \\
\text { aggregatum }\end{array}$ & $\begin{array}{l}\text { Shoot tips } \\
(2-3 \mathrm{~mm})\end{array}$ & $\begin{array}{l}\text { MS supple- } \\
\text { mented with } \\
30 \mathrm{~g} / \mathrm{L} \\
\text { sucrose, } \\
0.5 \mathrm{mg} / \mathrm{L} \mathrm{BA}, \\
0.1 \mathrm{mg} / \mathrm{L} \\
\text { NAA and } \\
8 \mathrm{~g} / \mathrm{L} \text { agar }\end{array}$ & $\begin{array}{c}\text { PVS3 at } \\
24^{\circ} \mathrm{C} \text { for } 3 \mathrm{~h}\end{array}$ & $\begin{array}{l}\text { LN storage } \\
\text { for } 1 \mathrm{~h}\end{array}$ & $\begin{array}{l}\text { Preculture } \\
\text { Medium for } \\
8 \text { weeks }\end{array}$ & NR & $\begin{array}{l}\text { No differences } \\
\text { in rooting, } \\
\text { vegetative } \\
\text { growth, bulb } \\
\text { production, } \\
\text { and contents } \\
\text { of soluble } \\
\text { sugars and } \\
\text { flavonols } \\
\text { between the } \\
\text { cryo- and } \\
\text { in vitro- } \\
\text { derived plants. } \\
\text { No polymor- } \\
\text { phisms found } \\
\text { in the } \\
\text { cryo-derived } \\
\text { plants by ISSR } \\
\text { and } \\
\text { AFLP Markers. }\end{array}$ & [151] \\
\hline $\begin{array}{l}\text { Helianthus } \\
\text { tuberosus } \\
\text { 'M6' } \\
\text { 'Relikt' } \\
\text { 'Shudi' } \\
\text { 'Stampede' }\end{array}$ & $\begin{array}{l}\text { Shoot tips } \\
(2-3 \mathrm{~mm})\end{array}$ & $\begin{array}{l}\text { Liquid MS } \\
\text { Medium } \\
\text { with } 0.4 \mathrm{M} \\
\text { sucrose }(3 \mathrm{~d})\end{array}$ & $\begin{array}{c}\text { LS: } 2.0 \mathrm{M} \\
\text { glycerol + } \\
0.4 \mathrm{M} \text { sucrose } \\
\text { (30 min) and } \\
\text { PVS2 at } 0{ }^{\circ} \mathrm{C} \\
(15 \mathrm{~min})\end{array}$ & $\begin{array}{l}\text { LN storage } \\
\text { for } 1 \mathrm{~d} \text {. } \\
\text { Rewarming } \\
\text { in RS at } 25^{\circ} \mathrm{C} \\
\text { for } 20 \mathrm{~min}\end{array}$ & $\begin{array}{c}\text { MS Medium } \\
\text { with } 0.29 \mu \mathrm{M} \\
\text { GA, } 15 \% \\
\text { sucrose, and } \\
8 \% \text { agar } \\
\text { cultured in } \\
\text { the dark for } \\
3-5 \mathrm{~d} \text {, and } \\
\text { then } \\
\text { under } 14 \mathrm{~h} \\
\text { photoperiod }\end{array}$ & $93(83)$ & $\begin{array}{l}\text { minimal cellu- } \\
\text { lar damage } \\
\text { observed } \\
\text { within the } \\
\text { Meristem cells } \\
\text { of the shoot } \\
\text { tips. No } \\
\text { polymor- } \\
\text { phism detected } \\
\text { by SSRs. }\end{array}$ & {$[62]$} \\
\hline
\end{tabular}


Table 4. Cont.

\begin{tabular}{|c|c|c|c|c|c|c|c|c|}
\hline $\begin{array}{c}\text { Biological } \\
\text { Material }\end{array}$ & Explant & Preculture & Pretreatment & $\begin{array}{l}\text { Storage and } \\
\text { Rewarming }\end{array}$ & Recovery & $\begin{array}{l}\text { S(R) } \\
(\%)\end{array}$ & Remarks & Ref. \\
\hline $\begin{array}{l}\text { Oxalis } \\
\text { tuberosa } \\
\text { and } \\
\text { Ullucus } \\
\text { tuberosus }\end{array}$ & $\begin{array}{l}\text { Shoot tips } \\
(2 \mathrm{~mm})\end{array}$ & $\begin{array}{c}\text { MS } \\
\text { semisolid } \\
\text { Medium } \\
\text { with } 2 \% \\
\text { sucrose, } \\
2 \mathrm{mg} / \mathrm{L} \\
\text { calcium } \\
\text { pantothenate, } \\
10 \mathrm{mg} / \mathrm{L} \\
\text { putrescine, } \\
0.25 \mathrm{mg} / \mathrm{L} \\
\text { GA for oca; } \\
\text { and with } 2 \% \\
\text { sucrose and } \\
2 \text { mg/L } \\
\text { calcium } \\
\text { pantothenate } \\
\text { for ulluco }\end{array}$ & $\begin{array}{c}\text { LS: } 2 \mathrm{M} \\
\text { glycerol and } \\
0.4 \\
\text { M sucrose } \\
\text { in MS } \\
\text { Medium at } \\
\text { RT for } 20 \mathrm{~min} . \\
\text { PVS2 for } \\
60 \mathrm{~min} \text {, at } \\
0^{\circ} \mathrm{C}\end{array}$ & $\begin{array}{l}\text { LN storage } \\
\text { for } 30 \text { min. } \\
\text { Rewarming } \\
\text { in RS for } \\
20 \text { min at RT }\end{array}$ & $\begin{array}{c}\text { MS with, } \\
0.3 \mathrm{M} \\
\text { sucrose, } \\
0.04 \mathrm{mg} / \mathrm{L} \\
\text { KIN, } \\
0.1 \mathrm{mg} / \mathrm{L} \mathrm{GA} \text {, } \\
\text { and } 0.28 \% \\
\text { phytagel, } \\
\text { incubated in } \\
\text { the dark for } \\
2 \mathrm{~d} \text {. } \\
\text { Then, } 0.1 \mathrm{M} \\
\text { su- } \\
\text { crose/dark/2 d. } \\
\text { Finally, MS } \\
\text { Medium } \\
\text { with } 0.07 \mathrm{M} \\
\text { sucrose+ } 2 \mathrm{M} \\
/ \mathrm{L} \text { calcium } \\
\text { pantothenate } \\
\text { at } 20{ }^{\circ} \mathrm{C}\end{array}$ & $\begin{array}{l}15 \text { and } \\
35, \\
\text { respec- } \\
\text { tively }\end{array}$ & $\begin{array}{l}\text { The protocols } \\
\text { efficiency } \\
\text { requires } \\
\text { further } \\
\text { improvement. }\end{array}$ & [131] \\
\hline $\begin{array}{c}\text { S. } \\
\text { tuberosum } \\
\text { ‘Agrie dzel- } \\
\text { tenie' } \\
\text { 'Anti' } \\
\text { 'Bintje' } \\
\text { 'Désirée' } \\
\text { 'Maret' }\end{array}$ & $\begin{array}{l}\text { Shoot tips } \\
(1-3 \mathrm{~mm})\end{array}$ & $\begin{array}{l}\text { MS solution } \\
\text { with } 3 \% \\
\text { sucrose }\end{array}$ & $\begin{array}{l}10 \% \text { dMSO in } \\
\text { liquid MS }\end{array}$ & $\begin{array}{l}\text { LN storage } \\
\text { for } 1 \mathrm{~h} \text {. } \\
\text { Rewarming } \\
\text { at RT in } \\
\text { liquid MS }\end{array}$ & $\begin{array}{l}\text { MS Medium } \\
\text { with } \\
0.5 \mathrm{mg} / \mathrm{L} \\
\text { zeatin } \\
\text { riboside, } \\
0.2 \mathrm{mg} / \mathrm{L} \mathrm{GA}, \\
0.5 \mathrm{mg} / \mathrm{L} \\
\text { IAA, } 30 \mathrm{~g} / \mathrm{L} \\
\text { sucrose }\end{array}$ & $17.1-52.6$ & $\begin{array}{c}\text { The } \\
\text { optimization of } \\
\text { light } \\
\text { spectra during } \\
\text { the recovery } \\
\text { phase is a } \\
\text { promising tool } \\
\text { for increasing } \\
\text { the recovery of } \\
\text { potato shoot } \\
\text { tips after cryop- } \\
\text { reservation. }\end{array}$ & [156] \\
\hline $\begin{array}{l}\text { S. } \\
\text { tuberosum } \\
\text { 'Désirée' } \\
\text { S. commer- } \\
\text { sonii dun. }\end{array}$ & $\begin{array}{l}\text { Shoot-tips } \\
(1 \times 0.5 \mathrm{~mm}) \text {, } \\
3 \text { weeks old }\end{array}$ & $\begin{array}{c}\text { MS Medium } \\
\text { with } 0.21 \mathrm{M} \\
\text { sucrose at } \\
6^{\circ} \mathrm{C}, 16 / 8- \\
\text { hour } \mathrm{d} / \mathrm{n} \\
\text { and a light } \\
\text { intensity of } \\
50 \mu \mathrm{mol} \mathrm{M}{ }^{-2} \\
\mathrm{~s}^{-1} \text { for } 2 \\
\text { weeks }\end{array}$ & $\begin{array}{c}\text { LS: } 2 \mathrm{M} \\
\text { glycerol and } \\
0.4 \mathrm{M} \text { sucrose } \\
\text { in MS } \\
\text { Medium } \\
\text { (20 min). } \\
\text { PVS2 for } \\
50 \text { min at } \\
0{ }^{\circ} \mathrm{C}\end{array}$ & $\begin{array}{l}\text { LN storage } \\
\text { for } 30 \text { min. } \\
\text { Rewarming } \\
\text { at RT in RS } \\
\text { (20 min) }\end{array}$ & $\begin{array}{l}\text { MS Medium } \\
\text { with } 0.3 \mathrm{M} \\
\text { sucrose }(1 \mathrm{~d}) \text {. } \\
\text { and then } \\
0.09 \mathrm{M} \\
\text { sucrose in } \\
\text { the dark for } \\
\text { the first } 7 \mathrm{~d}\end{array}$ & $>80$ & $\begin{array}{l}\text { First study in } \\
\text { which cryop- } \\
\text { reservation } \\
\text { experiments } \\
\text { are combined } \\
\text { with the } \\
\text { observation of } \\
\text { the responses } \\
\text { to abiotic stress } \\
\text { exposure. }\end{array}$ & [157] \\
\hline $\begin{array}{c}\text { S. } \\
\text { tuberosum } \\
\text { 'Zihuabai' }\end{array}$ & $\begin{array}{l}\text { Nodal } \\
\text { segments } \\
(1 \mathrm{~cm})\end{array}$ & $\begin{array}{c}\text { MS with } \\
0.3 \mathrm{M} \text { sucrose } \\
\text { in the dark at } \\
5{ }^{\circ} \mathrm{C} \text { for } 3 \mathrm{~d}\end{array}$ & $\begin{array}{c}\text { LS: } 2 \mathrm{M} \\
\text { glycerol and } \\
0.4 \mathrm{M} \text { sucrose } \\
\text { in MS. } \\
\text { PVS2 at } 0{ }^{\circ} \mathrm{C} \\
\text { for } 40 \mathrm{~min}\end{array}$ & $\begin{array}{l}\text { LN storage } \\
\text { for } 1 \mathrm{~h} \text {. } \\
\text { Rewarming } \\
\text { in a water } \\
\text { bath at } 38^{\circ} \mathrm{C} \\
\text { for } 2 \text { min and } \\
\text { then in } 1.2 \mathrm{M} \\
\text { sucrose at } \\
25^{\circ} \mathrm{C} \text { for } \\
20 \mathrm{~min}\end{array}$ & $\begin{array}{c}\text { MS supple- } \\
\text { mented with } \\
0.5 \mathrm{mg} / \mathrm{L} \\
\text { IAA, } \\
0.5 \mathrm{mg} / \mathrm{L} \mathrm{ZR} \\
\text { and } 0.2 \mathrm{mg} / \mathrm{L} \\
\text { GA and kept } \\
\text { in the dark at } \\
22 \pm 2{ }^{\circ} \mathrm{C} \text { for } \\
3 \mathrm{~d}\end{array}$ & $\begin{array}{c}\sim 80 \\
(72.5)\end{array}$ & $\begin{array}{l}\text { No genetic } \\
\text { alterations } \\
\text { were detected } \\
\text { in the } \\
\text { recovered } \\
\text { shoots by ISSR } \\
\text { and AFLP. }\end{array}$ & [39] \\
\hline
\end{tabular}


Table 4. Cont.

\begin{tabular}{|c|c|c|c|c|c|c|c|c|}
\hline $\begin{array}{c}\text { Biological } \\
\text { Material }\end{array}$ & Explant & Preculture & Pretreatment & $\begin{array}{l}\text { Storage and } \\
\text { Rewarming }\end{array}$ & Recovery & $\begin{array}{l}\mathrm{S}(\mathrm{R}) \\
(\%)\end{array}$ & Remarks & Ref. \\
\hline $\begin{array}{c}\text { S. ajanhuiri } \\
\text { 'Wila Yari' } \\
\text { CIP702650 } \\
\text { S. } \\
\text { commersonii } \\
\text { CGN18024, } \\
\text { S. juzepcukii } \\
\text { 'Piñaza' } \\
\text { CIP702445 } \\
\text { S. } \\
\text { tuberosum } \\
\text { 'Désirée' } \\
\text { CIP800048 }\end{array}$ & $\begin{array}{l}\text { Shoot tips } \\
(1 \times 0.5 \mathrm{~mm})\end{array}$ & $\begin{array}{l}\text { MS Medium } \\
\text { with } \\
0.3 \mathrm{M} / 0.09 \mathrm{M} \\
\text { sucrose at } \\
6^{\circ} \mathrm{C} \text { for } 14 \mathrm{~d}\end{array}$ & $\begin{array}{c}\text { LS: } 2 \mathrm{M} \\
\text { glycerol and } \\
0.4 \mathrm{M} \text { sucrose } \\
\text { in MS for } \\
20 \text { min in } \\
\text { the dark, at } \\
\text { RT. } \\
\text { PVS2 for } \\
50 \text { min at } \\
0{ }^{\circ} \mathrm{C}\end{array}$ & $\begin{array}{l}\text { LN storage } \\
\text { for } 30 \text { min. } \\
\text { Rewarming } \\
\text { in RS at RT } \\
\text { (20 min) }\end{array}$ & $\begin{array}{l}\text { MS Medium } \\
\text { with } 0.3 \mathrm{M} \\
\text { sucrose } \\
\text { solidified } \\
\text { with } 0.25 \% \\
\text { gerlite for } 1 \mathrm{~d} \\
\text { and transfer } \\
\text { to MS with } \\
0.09 \mathrm{M} \\
\text { sucrose }\end{array}$ & 90-100 & $\begin{array}{l}\text { The increased } \\
\text { accumulation } \\
\text { of sucrose and } \\
\text { raffinose family } \\
\text { of oligosaccha- } \\
\text { rides play a } \\
\text { fundamental } \\
\text { role in the } \\
\text { response to } \\
\text { stress in potato } \\
\text { and May help } \\
\text { to acquire } \\
\text { tolerance to } \\
\text { cryopreserva- } \\
\text { tion. }\end{array}$ & [158] \\
\hline $\begin{array}{l}\text { S. commer- } \\
\text { sonii, } \\
\text { S. } \\
\text { tuberosum } \\
\text { spp. } \\
\text { andigena, } \\
\text { S. } \\
\text { tuberosum } \\
\text { spp. } \\
\text { tuberosum, } \\
\text { S. } \times \\
\text { ajanhuiri, } \\
\text { S. } \times \\
\text { juzepczukii }\end{array}$ & $\begin{array}{l}\text { Shoot tips } \\
(1.8-2.5 \mathrm{~mm}) \text {, } \\
3 \text { weeks old }\end{array}$ & $\begin{array}{c}\text { MS salts } \\
\text { with } \\
0.04 \mathrm{mg} / \mathrm{L} \\
\mathrm{KIN}, \\
0.1 \mathrm{mg} / \mathrm{L} \mathrm{GA}, \\
0.07 \mathrm{M} \text { or } \\
0.03 \mathrm{M} \\
\text { sucrose and } \\
2.8 \mathrm{~g} / \mathrm{L} \\
\text { Phytagel at } \\
6^{\circ} \mathrm{C} \text { and RT } \\
\text { for } 1 \mathrm{~h}\end{array}$ & $\begin{array}{c}\text { LS: } 2 \mathrm{M} \\
\text { glycerol and } \\
0.4 \mathrm{M} \text { sucrose } \\
\text { for } 15 \text { min at } \\
\text { RT } \\
\text { PVS2 for } \\
50 \text { min on ice }\end{array}$ & $\begin{array}{l}\text { LN storage } \\
\text { for } 1 \mathrm{~h} . \\
\text { Rewarming } \\
\text { in RS at RT } \\
\text { (15-20 min). } \\
\text { in the dark }\end{array}$ & $\begin{array}{c}\text { MS salts } \\
\text { with } \\
0.04 \mathrm{mg} / \mathrm{L} \\
\mathrm{KIN} \\
0.1 \mathrm{mg} / \mathrm{L} \mathrm{GA} \text {, } \\
2.8 \mathrm{~g} / \mathrm{L} \\
\text { phytagel + } \\
0.3 \mathrm{M} \\
\text { sucrose. daily } \\
\text { transfers } \\
\text { from } 0.3 \text {, to } \\
0.2, \text { to } 0.1 \mathrm{M} \\
\text { and } \\
\text { finally Main- } \\
\text { tained on } \\
0.07 \mathrm{M} \\
\text { sucrose at } \\
22{ }^{\circ} \mathrm{C}, 16 \mathrm{~h} \\
\text { photoperiod }\end{array}$ & $40-100$ & $\begin{array}{l}\text { This Method is } \\
\text { recommended } \\
\text { for the } \\
\text { long-term } \\
\text { conservation } \\
\text { of diverse } \\
\text { accessions of } \\
\text { potato } \\
\text { germplasm. }\end{array}$ & [99] \\
\hline $\begin{array}{l}\text { Solanum } \\
\text { tuberosum } \\
\text { 'Agrie' } \\
\text { 'Anti' } \\
\text { 'Bintje' } \\
\text { 'Désirée' } \\
\text { 'Dzeltenie' } \\
\text { 'Maret' }\end{array}$ & $\begin{array}{l}\text { Shoot tips } \\
(1-3 \mathrm{~mm})\end{array}$ & $\begin{array}{l}\text { MS Medium } \\
\text { with } 2 \% \\
\text { sucrose and } \\
6.4 \mathrm{~g} / \mathrm{L} \text { agar } \\
\text { under } \\
\text { various light } \\
\text { spectra } \\
\text { conditions at } \\
22{ }^{\circ} \mathrm{C}\end{array}$ & $\begin{array}{l}\text { LS: MS- } \\
\text { solution with } \\
3 \% \text { sucrose } \\
\text { under the } \\
\text { original light } \\
\text { quality } \\
\text { treatments } \\
\text { overnight. } \\
\text { dehydration } \\
\text { for } 2 \text { h in MS- } \\
\text { solution with } \\
10 \% \text { dMSO }\end{array}$ & $\begin{array}{l}\text { LN storage } \\
\text { for } 1 \mathrm{~h} \text {. } \\
\text { Rewarmed } \\
\text { by dipping } \\
\text { the foils with } \\
\text { shoot tips } \\
\text { into } 30 \mathrm{ML} \\
\text { of MS } \\
\text { solution at } \\
\text { RT }\end{array}$ & $\begin{array}{c}\text { MS Medium } \\
\text { with } \\
0.5 \mathrm{mg} / \mathrm{L} \mathrm{ZR,} \\
0.2 \mathrm{mg} / \mathrm{L} \mathrm{GA}, \\
0.5 \mathrm{mg} / \mathrm{L} \\
\mathrm{IAA}, 30 \mathrm{~g} / \mathrm{L} \\
\text { sucrose and } \\
(1 \mathrm{ML} / \mathrm{L}) \\
\text { PPM }\end{array}$ & $\begin{array}{l}31-66 \\
\text { using } \\
\text { blue } \\
\text { light }\end{array}$ & $\begin{array}{l}\text { Light spectral } \\
\text { quality before } \\
\text { cryopreserva- } \\
\text { tion can } \\
\text { significantly } \\
\text { affect the cry- } \\
\text { opreservation } \\
\text { success of } \\
\text { potato shoot } \\
\text { tips. }\end{array}$ & [119] \\
\hline
\end{tabular}


Table 4. Cont.

\begin{tabular}{|c|c|c|c|c|c|c|c|c|}
\hline $\begin{array}{c}\text { Biological } \\
\text { Material }\end{array}$ & Explant & Preculture & Pretreatment & $\begin{array}{l}\text { Storage and } \\
\text { Rewarming }\end{array}$ & Recovery & $\begin{array}{l}S(R) \\
(\%)\end{array}$ & Remarks & Ref. \\
\hline $\begin{array}{c}\text { S. } \\
\text { tuberosum } \\
\text { 'Blue } \\
\text { Congo' } \\
\text { 'E03-2677' }\end{array}$ & $\begin{array}{l}\text { Buds } \\
(1.0-1.4 \mathrm{~mm})\end{array}$ & $\begin{array}{c}\text { MS with } \\
0.3 \mathrm{M} \text { sucrose } \\
\text { at } 4^{\circ} \mathrm{C} \text { and } \\
16 \mathrm{~h} \\
\text { photoperiod } \\
\text { for } 3 \text { weeks }\end{array}$ & $\begin{array}{l}\text { LS: MS with } \\
0.1 \mathrm{M} \text { sucrose } \\
\text { and } 2 \mathrm{M} \\
\text { glycerol for } \\
30 \text { min on ice. } \\
\text { PVS2 for } \\
30 \text { to } 40 \text { min } \\
\text { on ice }\end{array}$ & $\begin{array}{l}\text { LN storage } \\
\text { for } 1 \mathrm{~h} \text {. } \\
\text { Rewarming } \\
\text { in a water } \\
\text { bath at } 38^{\circ} \mathrm{C} \\
\text { for } 2 \mathrm{~min}\end{array}$ & $\begin{array}{l}\text { MS Medium } \\
\text { with } \\
0.2 \mathrm{mg} / \mathrm{L} \mathrm{GA} \text {, } \\
0.5 \mathrm{mg} / \mathrm{L} \\
\text { IAA, and ZR } \\
\text { for } 3 \mathrm{~d} \text { in } \\
\text { the dark. } \\
\text { Then, MS } \\
\text { with } \\
0.05 \mathrm{mg} / \mathrm{L} \\
\text { GA in light }\end{array}$ & $(70-80)$ & $\begin{array}{l}\text { First report on } \\
\text { cryopreserva- } \\
\text { tion of } \\
\text { purple-fleshed } \\
\text { potato by } \\
\text { vitrification- } \\
\text { based } \\
\text { procedures. } \\
\text { Larger explants } \\
\text { (1.5-2.0 mm) } \\
\text { were less } \\
\text { effective. }\end{array}$ & [104] \\
\hline $\begin{array}{c}\text { S. } \\
\text { tuberosum } \\
(28 \\
\text { genotypes) }\end{array}$ & $\begin{array}{c}\text { Shoot } \\
\text { apices } \\
(2-3 \mathrm{~mm})\end{array}$ & $\begin{array}{l}\text { Liquid MS } \\
\text { Medium } \\
\text { with } 0.3 \mathrm{M} \\
\text { sucrose for } \\
\text { 16-20 h }\end{array}$ & $\begin{array}{l}\text { LS: } 0.4 \mathrm{M} \\
\text { sucrose and } \\
2 \mathrm{M} \text { glycerol } \\
\text { in MS for } \\
20 \mathrm{~min} \text { and } \\
\text { PVS3 for } 2 \mathrm{~h}\end{array}$ & $\begin{array}{l}\text { LN storage } \\
\text { for } 1 \mathrm{~h} \text {. } \\
\text { Rewarming } \\
\text { at } 40{ }^{\circ} \mathrm{C} \text {, } \\
\text { unloading in } \\
\text { RS }(20 \mathrm{~min}) \\
\text { recovered } \\
25 / 20^{\circ} \mathrm{C} \mathrm{d} / \mathrm{n} \\
\text { or only } 20^{\circ} \mathrm{C} \\
\text { for } 7 \mathrm{~d}\end{array}$ & $\begin{array}{l}\text { MS Medium } \\
\text { with } 0.09 \mathrm{M} \\
\text { sucrose, } \\
0.5 \mathrm{mg} / \mathrm{L} \mathrm{ZR} \text {, } \\
0.2 \mathrm{mg} / \mathrm{L} \mathrm{GA} \text {, } \\
0.5 \mathrm{mg} / \mathrm{L} \\
\mathrm{IAA} \text { at } \\
25 / 20^{\circ} \mathrm{C} \mathrm{d} / \mathrm{n} \\
\text { temperature } \\
\text { in the dark } \\
(7 \mathrm{~d})\end{array}$ & $(71)$ & $\begin{array}{l}\text { All } 28 \text { geno- } \\
\text { types had higher } \\
\text { regrowth after } \\
\text { cryopreserva- } \\
\text { tion using } \\
\text { PVS3 instead } \\
\text { of dMSO. }\end{array}$ & [154] \\
\hline $\begin{array}{c}\text { Potato } \\
\text { varieties } \\
\text { (Solanum } \\
\text { spp.) }\end{array}$ & $\begin{array}{l}\text { Shoot tips } \\
\text { with } 3-4 \\
\text { leaf } \\
\text { primordia } \\
\text { (length: } \\
0.8-1.2 \mathrm{~mm} \text {; } \\
\text { width: } \\
0.4-0.7 \mathrm{~mm} \text { ) }\end{array}$ & $\begin{array}{c}\text { MS Medium } \\
\text { with } \\
0.04 \mathrm{mg} / \mathrm{L} \\
\mathrm{KIN}, \\
0.1 \mathrm{mg} / \mathrm{L} \mathrm{GA}, \\
25 \mathrm{~g} / \mathrm{L} \\
\text { sucrose and } \\
2.8 \mathrm{~g} / \mathrm{L} \\
\text { Phytagel }\end{array}$ & $\begin{array}{l}\text { LS: } 2.0 \mathrm{M} \\
\text { glycerol and } \\
0.4 \mathrm{M} \text { sucrose } \\
\text { in MS at RT } \\
\text { for } 20 \mathrm{~min} . \\
\text { PVS2 on ice } \\
\text { for } 50 \mathrm{~min}\end{array}$ & $\begin{array}{l}\text { LN storage } \\
\text { for } 24 \mathrm{~h} . \\
\text { Rewarming } \\
\text { in liquid MS } \\
\text { Medium } \\
\text { with } \\
0.0-1.2 \mathrm{M} \\
\text { sucrose for } \\
20 \text { min at RT }\end{array}$ & $\begin{array}{l}\text { MS Medium } \\
\text { with } \\
0.4 \mathrm{Mg} / 1 \\
\mathrm{KIN}, \\
0.1 \mathrm{mg} / \mathrm{L} \mathrm{GA}, \\
20 \mathrm{ML} / \mathrm{L} \\
\text { coconut } \\
\text { water, } 0.3 \mathrm{M} \\
\text { sucrose, } \\
2.8 \mathrm{~g} / \mathrm{L} \\
\text { Phytagelfor } \\
4 \mathrm{~d} \\
\text { under diffuse } \\
\text { light at } \\
18-22{ }^{\circ} \mathrm{C} \\
\text { with a } 16 \mathrm{~h} \\
\text { photoperiod }\end{array}$ & $\begin{array}{l}74.6-90.7 \\
(66.5-86.8)\end{array}$ & $\begin{array}{l}\text { The specific } \\
\text { response to } \\
\text { low }(0.0 \mathrm{M}) \\
\text { and high } \\
(1.2 \mathrm{M}) \\
\text { concentrations } \\
\text { of sucrose } \\
\text { in the } \\
\text { unloading } \\
\text { solution } \\
\text { was highly } \\
\text { variable within } \\
\text { species / } \\
\text { subspecies and } \\
\text { appears to be } \\
\text { genotype- } \\
\text { specific. }\end{array}$ & [67] \\
\hline \multicolumn{9}{|c|}{ Encapsulation-Vitrification } \\
\hline $\begin{array}{l}\text { Solanum } \\
\text { tuberosum } \\
\text { 'Zihuabai' }\end{array}$ & $\begin{array}{l}\text { Nodal } \\
\text { segments } \\
(1 \mathrm{~cm})\end{array}$ & $\begin{array}{c}\text { MS with } \\
0.3 \mathrm{M} \text { sucrose } \\
(1 \mathrm{~d}) \text { and } \\
\text { then } \\
\text { suspended } \\
\text { in MS with } \\
2.5 \%(w / v) \\
\text { alginate and } \\
0.4 \text { M sucrose }\end{array}$ & $\begin{array}{c}\text { LS: } 2 \mathrm{M} \\
\text { glycerol and } \\
0.6 \mathrm{M} \text { sucrose } \\
\text { in MS for } \\
90 \text { min and } \\
\text { then dehy- } \\
\text { drated with } \\
\text { PVS2 at } 0^{\circ} \mathrm{C} \\
\text { for } 4 \mathrm{~h}\end{array}$ & $\begin{array}{l}\text { LN storage } \\
\text { for } 1 \mathrm{~h} \text {. } \\
\text { Rewarming } \\
\text { in a water } \\
\text { bath at } 38^{\circ} \mathrm{C} \\
\text { for } 2 \text { min and } \\
\text { then in } 1.2 \mathrm{M} \\
\text { sucrose at } \\
25^{\circ} \mathrm{C} \text { for } \\
20 \mathrm{~min}\end{array}$ & $\begin{array}{c}\text { MS supple- } \\
\text { mented with } \\
0.5 \mathrm{mg} / \mathrm{L} \\
\text { IAA, } \\
0.5 \mathrm{mg} / \mathrm{L} \mathrm{ZR} \\
\text { and } 0.2 \mathrm{mg} / \mathrm{L} \\
\text { GA and kept } \\
\text { in the dark at } \\
22 \pm 2{ }^{\circ} \mathrm{C} \text { for } \\
3 \mathrm{~d}\end{array}$ & 70 & $\begin{array}{c}\text { No genetic } \\
\text { alterations } \\
\text { were detected } \\
\text { by ISSR and } \\
\text { AFLP. }\end{array}$ & [39] \\
\hline
\end{tabular}


Table 4. Cont.

\begin{tabular}{|c|c|c|c|c|c|c|c|c|}
\hline $\begin{array}{c}\text { Biological } \\
\text { Material }\end{array}$ & Explant & Preculture & Pretreatment & $\begin{array}{l}\text { Storage and } \\
\text { Rewarming }\end{array}$ & Recovery & $\begin{array}{l}\mathrm{S}(\mathrm{R}) \\
(\%)\end{array}$ & Remarks & Ref. \\
\hline $\begin{array}{l}\text { Solanum } \\
\text { tuberosum } \\
\text { ‘Blue } \\
\text { Congo' } \\
\text { 'E03-2677' }\end{array}$ & $\begin{array}{c}\text { Buds of } \\
1.5-2.0 \mathrm{~mm}\end{array}$ & $\begin{array}{c}\text { MS with } \\
0.3 \mathrm{M} \text { sucrose } \\
\text { at } 4{ }^{\circ} \mathrm{C} \text { and } \\
16 \mathrm{~h} \\
\text { photoperiod } \\
\text { for } 3 \text { weeks, } \\
\text { then } \\
\text { suspended in } \\
1 / 2 \mathrm{MS} \text { with } \\
3 \% \text { alginate, } \\
2 \mathrm{M} \text { glycerol, } \\
\text { and } \\
0.4 \mathrm{M} \text { sucrose }\end{array}$ & $\begin{array}{c}\text { MS } \\
\text { containing } \\
2 \mathrm{M} \text { glycerol } \\
\text { and } 0.6 \mathrm{M} \\
\text { sucrose at RT } \\
\text { for } 90 \mathrm{~min} \\
\text { and PVS2 on } \\
\text { ice for } 6-7 \mathrm{~h}\end{array}$ & $\begin{array}{l}\text { LN storage } \\
\text { for } 1 \mathrm{~h} \text {. } \\
\text { Rewarming } \\
\text { in a water } \\
\text { bath at } 38^{\circ} \mathrm{C} \\
\text { for } 2 \mathrm{~min}\end{array}$ & $\begin{array}{c}\text { MS Medium } \\
\text { with } \\
0.2 \mathrm{mg} / \mathrm{L} \mathrm{GA} \text {, } \\
0.5 \mathrm{mg} / \mathrm{L} \\
\text { IAA, and ZR } \\
\text { for } 3 \mathrm{~d} \text { in } \\
\text { the dark. } \\
\text { Then, MS } \\
\text { with } \\
0.05 \mathrm{mg} / \mathrm{L} \\
\text { GA in light }\end{array}$ & $(40-80)$ & $\begin{array}{l}\text { First report on } \\
\text { cryopreserva- } \\
\text { tion of } \\
\text { purple-fleshed } \\
\text { potato by } \\
\text { vitrification- } \\
\text { based } \\
\text { procedures. } \\
\text { Smaller } \\
\text { explants } \\
\text { (1.0-1.4 mm) } \\
\text { were less } \\
\text { effective. }\end{array}$ & [104] \\
\hline $\begin{array}{c}\text { S. } \\
\text { tuberosum } \\
\text { 'Zihuabai' }\end{array}$ & $\begin{array}{l}\text { Nodal } \\
\text { segments } \\
(1 \mathrm{~cm})\end{array}$ & $\begin{array}{l}\text { MS with } \\
0.45 \mathrm{M} \\
\text { sucrose in } \\
\text { the dark at } \\
5^{\circ} \mathrm{C} \text { for } 1 \mathrm{~d}\end{array}$ & $\begin{array}{l}\text { LS: } 2 \mathrm{M} \\
\text { glycerol and } \\
0.6 \mathrm{M} \text { sucrose } \\
\text { in MS for } \\
90 \mathrm{~min} . \\
\text { PVS2 at } 0{ }^{\circ} \mathrm{C} \\
\text { for } 4 \mathrm{~h}\end{array}$ & $\begin{array}{l}\text { LN storage } \\
\text { for } 1 \mathrm{~h} \text {. } \\
\text { Rewarming } \\
\text { in a water } \\
\text { bath at } 38^{\circ} \mathrm{C} \\
\text { for } 2 \text { min and } \\
\text { then in } 1.2 \mathrm{M} \\
\text { sucrose at } \\
25^{\circ} \mathrm{C} \text { for } \\
20 \mathrm{~min}\end{array}$ & $\begin{array}{c}\text { MS with } \\
0.5 \mathrm{mg} / \mathrm{L} \\
\text { IAA, } \\
0.5 \mathrm{mg} / \mathrm{L} \mathrm{ZR}, \\
0.2 \mathrm{mg} / \mathrm{L} \mathrm{GA} \text {, } \\
\mathrm{kept} \text { in } \\
\text { the dark at } \\
22{ }^{\circ} \mathrm{C} \text { for } 3 \mathrm{~d}\end{array}$ & $\sim 80(70)$ & $\begin{array}{l}\text { No genetic } \\
\text { alterations de- } \\
\text { tected in the } \\
\text { recovered } \\
\text { shoots by ISSR } \\
\text { and } \\
\text { AFLP Markers. }\end{array}$ & [39] \\
\hline \multicolumn{9}{|c|}{ Encapsulation-Dehydration } \\
\hline $\begin{array}{c}\text { A. officinalis } \\
\text { 'Morado de } \\
\text { huétor' }\end{array}$ & $\begin{array}{l}\text { Rhizome } \\
\text { buds }\end{array}$ & $\begin{array}{c}\text { MS with } \\
0.3 \mathrm{M} \text { sucrose } \\
\text { at } 25^{\circ} \mathrm{C} \text { for } \\
24 \text { or } 48 \mathrm{~h}\end{array}$ & $\begin{array}{c}\text { Explants } \\
\text { embedded in } \\
\text { alginate }(3 \%), \\
\text { sucrose } \\
(0.4 \mathrm{M}) \text { and } \\
\text { glycerol } \\
(2 \mathrm{M}) . \\
\text { desiccation } \\
\text { over silica gel } \\
\text { for } 24 \mathrm{~h}\end{array}$ & $\begin{array}{l}\text { LN storage } \\
\text { for } 24 \mathrm{~h} \text {. } \\
\text { Rewarming } \\
\text { in distilled } \\
\text { water at RT }\end{array}$ & $\begin{array}{l}\text { MS Modified } \\
\text { with Ferric } \\
\text { Sodium } \\
\text { EDDHA } \\
85.7 \mathrm{mg} / \mathrm{L}, \\
0.5 \mathrm{mg} / \mathrm{L} \\
\mathrm{NAA}, \\
0.7 \mathrm{mg} / \mathrm{L} \\
\text { kinetin, } \\
2 \mathrm{mg} / \mathrm{L} \\
\text { Ancymidol, } \\
\text { and } 6 \% \\
\text { sucrose }\end{array}$ & $34.5-84$ & $\begin{array}{l}\text { Confirmation } \\
\text { of ploidy } \\
\text { and Molecular } \\
\text { stability of } \\
\text { LN-recovered } \\
\text { plantlets. }\end{array}$ & [50] \\
\hline $\begin{array}{l}\text { Mentha } \times \\
\text { piperita } \\
\text { 'MEN } \\
198 '\end{array}$ & $\begin{array}{l}\text { Axillary } \\
\text { buds } \\
(1-2 \mathrm{~mm})\end{array}$ & $\begin{array}{l}\text { MS Medium } \\
\text { with } 0.3 \mathrm{M} \\
\text { sucrose for } \\
1 \mathrm{~d} \text { at RT and } \\
16 \mathrm{~h} \\
\text { photoperiod } \\
\text { at low light } \\
\text { intensity. } \\
\text { Explants } \\
\text { suspended } \\
\text { in MS with } \\
3 \% \text { alginate } \\
\text { and } 0.35 \mathrm{M} \\
\text { sucrose } \\
\text { (30 min) }\end{array}$ & $\begin{array}{l}\text { Osmotic de- } \\
\text { hydration } \\
\text { in MS liquid } \\
+0.75 \mathrm{M} \\
\text { sucrose at } \\
120 \mathrm{rpm} \text { for } \\
18-20 \mathrm{~h} \text {. } \\
\text { Then, drying } \\
\text { in a flow } \\
\text { chamber for } \\
5 \mathrm{~h} \text { to a level } \\
\text { of } 22 \% \text { initial } \\
\text { water content }\end{array}$ & $\begin{array}{l}\text { LN storage } \\
\text { for } 1 \mathrm{~d} \text {. } \\
\text { Rewarming } \\
\text { in a water } \\
\text { bath at } 40{ }^{\circ} \mathrm{C} \\
\text { for } 2 \mathrm{~min}\end{array}$ & NR & NR & $\begin{array}{l}\text { RAPD and } \\
\text { AFLP showed } \\
\text { an almost } \\
\text { complete } \\
\text { genetic } \\
\text { stability of the } \\
\text { recovered } \\
\text { plants. }\end{array}$ & [103] \\
\hline
\end{tabular}


Table 4. Cont.

\begin{tabular}{|c|c|c|c|c|c|c|c|c|}
\hline $\begin{array}{l}\text { Biological } \\
\text { Material }\end{array}$ & Explant & Preculture & Pretreatment & $\begin{array}{l}\text { Storage and } \\
\text { Rewarming }\end{array}$ & Recovery & $\begin{array}{l}S(R) \\
(\%)\end{array}$ & Remarks & Ref. \\
\hline $\begin{array}{l}\text { Solanum } \\
\text { phureja }\end{array}$ & $\begin{array}{l}\text { Single node } \\
\text { stem } \\
\text { cuttings } \\
(1 \mathrm{~cm})\end{array}$ & $\begin{array}{l}0.1 \text { M sucrose } \\
\text { in TR } \\
\text { Medium, MS } \\
\text { Microele- } \\
\text { ments, } \\
\text { vitamins } \\
\text { of MW } \\
\text { Medium for } \\
7 \text { d at RT, and } \\
16 \mathrm{~h} \\
\text { photoperiod. } \\
\text { Suspension } \\
\text { in } 3 \% \\
\text { alginate and } \\
0.1 \mathrm{M} \text { sucrose }\end{array}$ & $\begin{array}{l}\text { PC Medium } \\
\text { supple- } \\
\text { mented with } \\
\text { (sugars and } \\
\text { polyols) } \\
(0.65 \mathrm{M}) \text { for } \\
2 \mathrm{~d} \text { at RT. } \\
\text { dehydration } \\
\text { for } 4.5 \mathrm{~h} \text { on } \\
\text { silica gel to a } \\
\text { level of } 22 \% \\
\text { initial water } \\
\text { content }\end{array}$ & $\begin{array}{l}\text { LN storage } \\
\text { for } 1 \mathrm{~h} \text {. } \\
\text { Rewarming } \\
\text { at RT }\end{array}$ & PC Medium & $\begin{array}{l}88 \\
\text { (maltose) } \\
\text { and 91 } \\
\text { (trehalose) }\end{array}$ & $\begin{array}{l}\text { Maltose and } \\
\text { trehalose were } \\
\text { the Most } \\
\text { effective cry- } \\
\text { oprotectants. } \\
\text { Shoot tips } \\
\text { precultured in } \\
\text { sucrose, } \\
\text { trehalose or } \\
\text { glucose, } \\
\text { indicated an } \\
\text { increase in } \\
\text { total soluble } \\
\text { sugars, } \\
\text { especially } \\
\text { when sucrose } \\
\text { was applied } \\
\text { as a } \\
\text { cryoprotectant. }\end{array}$ & [146] \\
\hline \multicolumn{9}{|c|}{ Cryo-plate } \\
\hline $\begin{array}{l}\text { Allium spp. } \\
\text { A. sativum } \\
\quad \text { A. } \\
\text { fistulosum } \\
\text { var. caespi- } \\
\text { tosum } \\
\text { A. chinense }\end{array}$ & $\begin{array}{l}\text { Shoot tips } \\
(2.5 \mathrm{~mm}), \\
2 \text { days old }\end{array}$ & $\begin{array}{c}\frac{1}{2} \mathrm{MS} \\
\text { Medium } \\
\text { with } 0.3 \mathrm{M} \\
\text { sucrose for } \\
2 \mathrm{~d} \text {. Explants } \\
\text { embedded on } \\
\text { cryo-plates } \\
\text { with } 3 \% \\
\text { alginate and } \\
0.4 \mathrm{M} \text { sucrose } \\
\text { (15 min) }\end{array}$ & $\begin{array}{c}\text { LS: } 1.0 \mathrm{M} \\
\text { sucrose and } \\
2.0 \mathrm{M} \\
\text { glycerol } \\
(30 \mathrm{~min}) \text { at } \\
25^{\circ} \mathrm{C} \text {. } \\
\text { Air desicca- } \\
\text { tion for } 30 \text { to } \\
180 \text { min }\end{array}$ & $\begin{array}{l}\text { LN storage } \\
\text { for } 1 \mathrm{~h} \text {. } \\
\text { Rewarming } \\
\text { in } 1.0 \mathrm{M} \\
\text { sucrose } \\
\text { solution in } \\
1 / 2 \mathrm{MS} \\
\text { Medium at } \\
25^{\circ} \mathrm{C} \text { for } \\
30 \mathrm{~min}\end{array}$ & $\begin{array}{c}\frac{1}{2} \mathrm{MS} \\
\text { Medium } \\
\text { with } 3.0 \% \\
\text { sucrose and } \\
0.8 \% \text { agar }\end{array}$ & 94 & $\begin{array}{l}\text { The glass } \\
\text { transition } \\
\text { temperature of } \\
\text { shoot tips after } \\
\text { air desiccation } \\
\text { was }-39.4^{\circ} \mathrm{C} \text {. }\end{array}$ & [159] \\
\hline $\begin{array}{l}\text { Solanum } \\
\text { tuberosum } \\
\text { 'Sayaka' }\end{array}$ & $\begin{array}{l}\text { Shoot tips } \\
(0.5-1.5 \mathrm{~mm})\end{array}$ & $\begin{array}{l}\text { MS Medium } \\
+0.3 \mathrm{M} \\
\text { sucrose and } \\
0.3 \% \text { gellan } \\
\text { gum at } 25^{\circ} \mathrm{C} \\
\text { overnight. } \\
\text { Explants } \\
\text { embedded on } \\
\text { cryo-plates } \\
\text { with } 2 \% \\
\text { alginate } \\
(15 \text { min) }\end{array}$ & $\begin{array}{c}\text { LS: } 2.0 \mathrm{M} \\
\text { glycerol and } \\
0.8 \mathrm{M} \text { sucrose } \\
\text { in MS at } \\
25^{\circ} \mathrm{C} \text { for } \\
30 \text { min. } \\
\text { V cryo-plate: } \\
\text { PVS2 at } \\
25^{\circ} \mathrm{C} \text { for } \\
30 \text { min } \\
\text { d cryo-plate: } \\
\text { air desicca- } \\
\text { tion for } \\
2 \mathrm{~h}\end{array}$ & $\begin{array}{l}\text { LN storage } \\
\text { for } 30 \text { min. } \\
\text { Rewarming } \\
\text { in MS } \\
\text { Medium } \\
\text { with } 1 \mathrm{M} \\
\text { sucrose for } \\
15 \text { min at RT }\end{array}$ & PC Medium & $\begin{array}{l}\text { d cryo- } \\
\text { plate: } \\
\text { 93.3; } \\
\text { V cryo- } \\
\text { plate: } \\
96.7\end{array}$ & $\begin{array}{l}\text { Both protocols } \\
\text { will facilitate } \\
\text { efficient } \\
\text { strategies for } \\
\text { the } \\
\text { preservation, } \\
\text { storage, } \\
\text { and Mainte- } \\
\text { nance of } \\
\text { genetic } \\
\text { stability of } \\
\text { potato } \\
\text { germplasm. }\end{array}$ & [160] \\
\hline
\end{tabular}


Table 4. Cont.

\begin{tabular}{|c|c|c|c|c|c|c|c|c|}
\hline $\begin{array}{c}\text { Biological } \\
\text { Material }\end{array}$ & Explant & Preculture & Pretreatment & $\begin{array}{l}\text { Storage and } \\
\text { Rewarming }\end{array}$ & Recovery & $\begin{array}{l}\text { S(R) } \\
(\%)\end{array}$ & Remarks & Ref. \\
\hline $\begin{array}{l}\text { Ullucus } \\
\text { tuberosus } \\
11 \text { lines }\end{array}$ & $\begin{array}{l}\text { Shoot tips } \\
(1.0-1.5 \mathrm{~mm})\end{array}$ & $\begin{array}{l}\text { MS with } \\
0.3 \mathrm{M} \text { sucrose } \\
\text { for } 16 \mathrm{~h} \text { at } \\
25^{\circ} \mathrm{C}\end{array}$ & $\begin{array}{c}\text { d cryo-plate: } \\
\text { Alginate with } \\
0.4 \mathrm{M} \text { sucrose. } \\
\text { Cryo-plates + } \\
2 \mathrm{M} \text { glycerol } \\
+1 \mathrm{M} \text { sucrose } \\
\text { for } 90 \mathrm{~min} \text { at } \\
25^{\circ} \mathrm{C} \text {. } \\
\text { dehydration } \\
\text { at } 25^{\circ} \mathrm{C} \text { for } \\
45 \mathrm{~min}\end{array}$ & LN storage & - & $73-97$ & $\begin{array}{l}\mathrm{d} \text { cryo-plate is } \\
\text { a practical and } \\
\text { simple } \\
\text { procedure for } \\
\text { cryostorage of } \\
\text { in vitro grown } \\
\text { ulluco shoot } \\
\text { tips in an ex } \\
\text { situ genebank. }\end{array}$ & [132] \\
\hline \multicolumn{9}{|c|}{ Desiccation } \\
\hline $\begin{array}{l}\text { Potato: } \\
\text { 'Avon' } \\
\text { 'Ceza' } \\
\text { 'Climax' }\end{array}$ & $\begin{array}{l}\text { Microtu- } \\
\text { bers } \\
(\sim 2 \mathrm{~mm})\end{array}$ & $\begin{array}{l}\text { MS Medium } \\
\text { without } \\
\text { vitamins } \\
\text { with } 100 \mathrm{~g} / \mathrm{L} \\
\text { sucrose, and } \\
10 \mathrm{~g} / \mathrm{L} \text { agar }\end{array}$ & $\begin{array}{c}\text { Microtu- } \\
\text { ber desicca- } \\
\text { tion using } \\
\text { sterile dry } \\
\text { silica gel for } \\
\text { 3-6 h } \\
(17-36 \% \mathrm{FW})\end{array}$ & $\begin{array}{l}\text { LN storage } \\
\text { for } 10 \text { min. } \\
\text { Rewarming } \\
\text { in a water } \\
\text { bath at } 45^{\circ} \mathrm{C} \\
\text { for } 60 \mathrm{~s} \text { and } \\
\text { in a } \\
\text { liquid MS } \\
\text { Medium at } \\
\text { RT for } \\
5-10 \mathrm{~min}\end{array}$ & $\begin{array}{c}\text { MS with } \\
\text { vitamins, } \\
30 \mathrm{~g} / \mathrm{L} \\
\text { sucrose and } \\
2 \mathrm{~g} / \mathrm{L} \\
\text { activated } \\
\text { charcoal at } \\
25^{\circ} \mathrm{C} \text { with } \\
16 \mathrm{~h} \\
\text { photoperiod }\end{array}$ & 100 & $\begin{array}{l}\text { The desiccation } \\
\text { technique is a } \\
\text { simple } \\
\text { approach for } \\
\text { cryostorage } \\
\text { of Microtubers. }\end{array}$ & [147] \\
\hline
\end{tabular}

$\mathrm{S}(\mathrm{R})=$ Survival (recovery). $\mathrm{NR}=$ not reported. $\mathrm{RT}=$ room temperture. $\mathrm{RS}=$ rewarming solution. $\mathrm{d} / \mathrm{n}=\mathrm{day} / \mathrm{night}$.

AFLP, amplified fragment length polymorphism; AFP, antifreeze protein; dMSO, dimethyl sulfoxide; ISSR, intersequence simple repeats; LN, liquid nitrogen; LS, loading solution; MS, Murshige and Skoog [90] Medium; MW, Morel and Wetmore [161] Medium; PC, preculture; PVS, plant vitrification solution; RAPD, randomly amplified dNA; RS, Sakai's unloading solution [28]; TL, Tendille and Lecerf [162] Medium.

\section{Oxidative Stress Markers in LN-Derived Plant Material}

Managing oxidative stress is vital for the successful application of cryopreservation to plant tissues. Freezing injury induces the production of free radicals, Mainly ROS, which attack the lipid fraction of Membranes [112]. Even pre-LN storage steps, such as hardening and dehydration, can induce excess ROS such as hydroxyl radicle, superoxide, and hydrogen peroxide, which can accumulate and cause severe damage to plant tissues [163]. Lipid peroxidation is well documented as occurring under cryo-stress. Therefore, the levels of enzymatic and non-enzymatic oxidative Markers should be Measured when developing a new cryoprotocol.

In several plant species, including corn (Zea Mays L.)—one of the Most important grains in the world-it was reported that there is a strong relationship between the viability of LN-stored cells and the activity of superoxide dismutase (SOD), glutathione reductase (GR), peroxidase (POD), catalase (CAT), and ascorbic acid peroxidase (APX) [163-165]. As for kiwi (Actinidia chinensis Planch.), the presence of compounds known as protein carbonyls (PCO) was significantly affected by the cryopreservation procedure, leading researchers to conclude that PCO could serve as a Marker for protein oxidative damage [101].

To better understand the possible reasons for a reduction in the survival level at the subsequent steps of cryopreservation, Subbarayan et al. [166] Measured the concentration of amino acids, ammonium, $\gamma$-aminobutyric acid (GABA), soluble sugars, Malondialdehyde (MDA), and oxygen in garlic shoot tips undergoing cryopreservation. They found an altered Modulation in alanine and glutamate Metabolism at the dehydration step that May indicate hypoxic stress in the tissue. Furthermore, the accumulation of MDA was confirmed to play an important role in cryo-stress, indicating that the generation of ROS is highest after the hypoxic dehydration step. Further studies are needed that examine hypoxia during dehydration at the Molecular level. 


\section{Stability and Functional Genomics of LN-Derived Plant Material}

While cryopreserving genetic resources, emphasis has always been given to the genetic integrity of the stored Biological Material. This is particularly important in the commercial production of certified elite plant Material. It is assumed that once cryopreserved, biological samples remain safe and stable. Therefore, novel, Mutant, or transformed cell lines can be stored cryogenically to prevent their loss. Generally, there is consensus that genetic drift and Mutation occurrence are minimized under cryogenics compared to when samples are Maintained in an actively growing state for extended intervals [121]. For example, the study by Li et al. [104] showed no polymorphism in the LN-recovered plantlets of purple-fleshed potato after applying inter simple sequence repeat (ISSR) and randomly amplified polymorphic dNA (RAPD) Markers. Similarly, no Mutations were detected by sequence simple repeat (SSR) Molecular Markers in LN-derived Jerusalem artichoke (Helianthus tuberosus L.). As for the commercial sugarcane (Saccharum spp.) germplasm cryopreserved with two PVS-2-based procedures, $100 \%$ genetic homogeneity was detected by ISSRs from halaii and $\mathrm{h} 83-6179$ cultivars, whereas $98.5 \%$ genetic stability was detected from NG 57-024 cultivar (Kaya and Souza 2017). Similarly, no ploidy changes were detected by flow cytometry (FCM) in asparagus cryopreserved with the encapsulation-dehydration technique [50]. Nonetheless, the potential effects of cryostorage of explants and seeds on subsequent plant growth in ex vitro conditions Must be established before routine implementation in cryobanks, especially as genomic or phenotypic variation May result from tissue culture procedures commonly used in cryopreservation techniques. The dehydration phase (both physical and chemical in PVS) is the Most critical for the stability of the plant Material, as observed with spring wheat (Triticum aestivum L.) and tomato (Solanum lycopersicum L.) [167]. The duration of LN storage May also affect the parameters of plant Material. For example, different ISSR fragment patterns were recorded in vitrification-derived buds of grapevine as compared with the untreated control after storage for one hour, one week, and one Month [155]. As for wasabi (Wasabia japonica Matsumu), only a minor change in dNA sequence was found after two years of LN storage (when using the same technique) compared to the in vitro-grow control. however, when comparing the control and cryo-derived plant Material after 10 years of storage, More Mutations were found in the latter one [168]. Therefore, the vitrification technique seems to be the least 'safe' for long-term germplasm storage. This is probably due to the lack of additional physical protection present in the encapsulation-based techniques or slower cooling and rewarming rates than in the droplet-vitrification or cryo-plate techniques.

Recent studies revealed that dNA Methylation and histone acetylation patterns in plants May be affected by cryoprotectants and/or liquid nitrogen exposure [112]. This epigenetic variation May cause genomic changes when Methylation-sensitive Marker systems are employed. Maki et al. [168] reported Methylation changes in the dNA of wasabi after long-term storage of shoot tips at $-150^{\circ} \mathrm{C}$. Likewise, Ibáñeza et al. [103] found that mint apices sampled immediately after each step of the encapsulation-dehydration protocol showed increased epigenetic differences as the protocol advanced, compared to in vitro-grown control, particularly related to de novo Methylation events. however, after one-day in vitro recovery, Methylation status was similar to the control objects. Those authors developed a simple and fast Method for the analysis of Methylation-sensitive amplified polymorphism (MSAP) Markers, based on R programming, to improve the quality of Methylation data interpretation and graphical representation [103].

The structural and phytochemical profile of plant Material can also be More or less reversibly altered by the cryopreservation process [112]. In LN-derived tomato plants, the levels of cell wall-linked, free, and total phenolics decreased significantly in roots, stems, and leaves after 7-21 days of cryo-storage. Conversely, the concentration of the Mentioned above compounds increased when seeds were immersed in LN for 28 days compared to non-treated control [169]. As for LN-derived sorghum (Sorghum bicolor (L.) Moench.) seeds, at 0-14 days after rewarming, the content of chlorophyll $a$ was significantly higher than in the control samples, which May be attributed to the activity of enzymes related to chloro- 
phyll biosynthesis, such as $\delta$-aminolevulinic acid dehydratase and protochlorophyllide reductase. On the other hand, seedlings derived from cryopreserved seeds showed higher SOD and POD activities. Contrastingly, LN-derived and control adult plants were comparable in terms of chlorophylls, proteins, enzyme activities, plant architecture, and yield components [170].

Plant cryobiology also seeks to understand the Molecular processes that allow plants to survive low temperatures and to explain why some genotypes are less tolerant of cryopreservation stresses than others. Recent discoveries in functional genomics in Musa and Arabidopsis have revealed the involvement of genes and proteins in the glycolytic and other Metabolic pathways engaged in dehydration tolerance, osmoprotection, and Membrane transport leading to cold acclimation and freezing tolerance acquisition [121]. It was found that prolonged stress-related to dehydration-rehydration cycles and low temperature invoke secondary Messengers such as calcium, ROS, and inositol phosphates. The cascades initiating from these signal Molecules result in the expression of transcription factors (TF) that affect the expression of hundreds of stress response genes, such as chaperones, LEA (Late Embryogenesis Abundant), osmotin, antifreeze, MRNA binding, osmolyte biosynthesis, water channel proteins, sugar and proline transporters, proteases, and detoxification enzymes $[121,171]$. Moreover, the complex Mechanism of stress response in plants is not only controlled by genes but also by other factors, such as hormones, circadian clocks, and light [171]. Progress in genomic research May unravel fundamental physiological responses of cells to extreme conditions (including CPAs treatment, low temperatures, and in vitro recovery), the knowledge of which will guide cryobiologists in their quest to design improved long-term preservation strategies.

\section{Conclusions}

Cryopreservation Methods are used by world germplasm banks to preserve the biodiversity of vegetatively propagated plant species of agronomic importance (and/or those with recalcitrant seeds) as a reference/base collection for the available genetic diversity of a population or as a source for new alleles in the future breeding programs. The cryoprotocols are being constantly improved to increase cell viability, eradicate viral diseases, and Maintain the genetic stability of the germplasm. Recently, the field of plant cryobiology has advanced significantly through the use of Molecular techniques. The challenge is to achieve the Maximum versatility possible, which is why More studies Must be carried out to further decrease the cytotoxicity of cryoprotectants, in addition to creating new standard protocols applicable to a variety of germplasms of worldwide interest. Studies on the inclusion of antioxidants should be carried out to obtain better results of viability. The application of NPs and natural animal and/or plant extracts can help achieve this goal. Moreover, the characterization of specific genes and proteins involved in dehydration tolerance, osmoprotection, and Membrane transport in tissues will lead to significant advances in plant cryobiology research.

Author Contributions: Conceptualization, C.A.R.-B. and D.K.; investigation, C.A.R.-B. and D.K.; resources, D.K.; writing-original draft preparation, C.A.R.-B., A.V.d.S. and E.F.V.; writing-review and editing, E.F.V., D.K., A.V.d.S. and B.K.; visualization, D.K.; supervision, D.K. and E.F.V.; project administration, C.A.R.-B.; funding acquisition, D.K. and E.F.V. All authors have read and agreed to the published version of the Manuscript.

Funding: São Paulo Research Foundation/FAPESP (Process number 2016/00446-7) and Master scholarship (Proc. 2018/25707-3).

Institutional Review Board Statement: Not applicable.

Informed Consent Statement: Not applicable.

Data Availability Statement: Not applicable. 
Acknowledgments: The authors would like to thank the School of Sciences and Engineering (São Paulo State University-UNESP, Campus of Tupã). We also thank Jonathan dos Santos Viana from the department of Soil Sciences of FCAV/UNESP Brazil for the photographs used in Figure 1. This study was supported by the National Science Centre, Poland (project no. 2020/39/D/NZ9/01592).

Conflicts of Interest: The authors declare no conflict of interest.

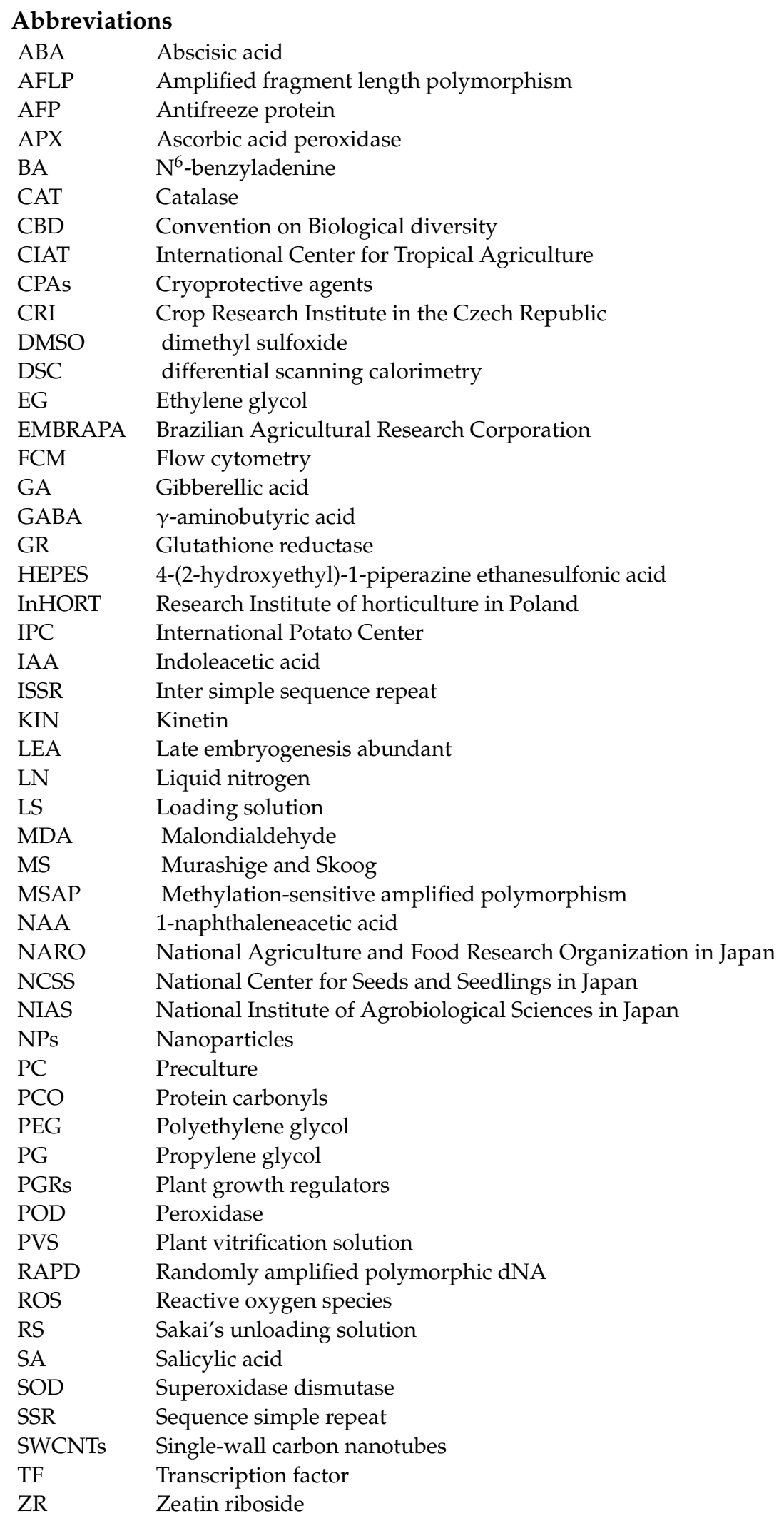




\section{References}

1. Milla, R. Crop Origins and Phylo Food: A database and a phylogenetic tree to stimulate comparative analyses on the origins of food crops. Glob. Ecol. Biogeogr. 2020, 29, 606-614. [CrossRef]

2. CBD, U. Convention on Biological diversity (with Annexes); Concluded at Rio de Janeiro on 5 June 1992; United Nations: Rio de Janeiro, Brazil, 1992.

3. Lambers, J.R.H. Extinction risks from climate change. Science (80-) 2015, 348, 501-502. [CrossRef]

4. Prevéy, J.S.; Parker, L.E.; harrington, C.A. Projected impacts of climate change on the range and phenology of three culturallyimportant shrub species. PLoS ONE 2020, 15, e0232537. [CrossRef] [PubMed]

5. Ruiz-Sáenz, d.R.; Ayala-Hernández, d.D.; Niino, T.; Cruz-Gutiérrez, E.J.; Aquino-Martínez, J.G.; López-Delgado, h.A. Salicylic acidcryotherapy treatment for elimination of potato virus $S$ from Solanum tuberosum. Am. J. Potato Res. 2019, 96, 225-234. [CrossRef]

6. Urban, M.C. Accelerating extinction risk from climate change. Science (80-) 2015, 348, 571-573. [CrossRef] [PubMed]

7. Urban, M.C.; Bocedi, G.; hendry, A.P.; Mihoub, J.B.; Peer, G.; Singer, A.; Bridle, J.R.; Crozier, L.G.; de Meester, L.; Godsoe, W.; et al. Improving the forecast for biodiversity under climate change. Science (80-) 2016, 353, aad8466. [CrossRef] [PubMed]

8. Pullman, G.S.; Bai, K.; hane, M.; Ruland, d.; Cruse-Sanders, J.M.; Boyd, R.S.; Johnson, S. Seed cryopreservation and Micropropagation of the federally threatened species, Price's potato-bean (Apios priceana B.L. Robins.). Vitro Cell. dev. Biol. Plant 2019, 55, 558-568. [CrossRef]

9. Ruta, C.; Lambardi, M.; Ozudogru, E.A. Biobanking of vegetable genetic resources by in vitro conservation and cryopreservation. Biodivers. Conserv. 2020, 29, 3495-3532. [CrossRef]

10. Fitzgerald, h.; Palmé, A.; Asdal, Å.; Endresen, d.; Kiviharju, E.; Lund, B.; Rasmussen, M.; Thorbjörnsson, h.; Weibull, J. A regional approach to Nordic crop wild relative in situ conservation planning. Plant Genet. Resour. Charact. Util. 2019, 17, 196-207. [CrossRef]

11. Vincent, h.; Amri, A.; Castañeda-Álvarez, N.P.; dempewolf, h.; dulloo, E.; Guarino, L.; hole, d.; Mba, C.; Toledo, A.; Maxted, N. Modeling of crop wild relative species identifies areas globally for in situ conservation. Commun. Biol. 2019, 2, 136. [CrossRef]

12. Ayuso, M.; García-Pérez, P.; Ramil-Rego, P.; Gallego, P.P.; Barreal, M.E. In vitro culture of the endangered plant Eryngium viviparum as dual strategy for its ex situ conservation and source of bioactive compounds. Plant Cell. Tissue Organ Cult. 2019, 138, 427-435. [CrossRef]

13. Amano, R.; Nakayama, h.; Momoi, R.; Omata, E.; Gunji, S.; Takebayashi, Y.; Kojima, M.; Ikematsu, S.; Ikeuchi, M.; Iwase, A.; et al. Molecular basis for natural vegetative propagation via regeneration in North American Lake Cress, Rorippa aquatica (Brassicaceae). Plant Cell Physiol. 2020, 61, 353-369. [CrossRef]

14. Guimarães, R.N.; Souza, E.R.B.d.; Naves, R.V.; Melo, A.P.C.d.; Rubio Neto, A. Vegetative propagation of pequi (souari nut) by cutting. Ciência Rural 2019, 49. [CrossRef]

15. Nagahama, N.; Manifesto, M.M.; Fortunato, R.H. Vegetative propagation and proposal for sustainable Management of Valeriana carnosa Sm., a traditional Medicinal plant from Patagonia. J. Appl. Res. Med. Aromat. Plants 2019, 14, 100218. [CrossRef]

16. Onyebuchi Okonkwo, h. Amenability of Cola Lepidota to vegetative propagation by Marcotting. Niger. J. Agric. Food Environ. 2020, 16, 7-13.

17. Kulus, d. Genetic resources and selected conservation Methods of tomato. J. Appl. Bot. Food Qual. 2018, 91, 135-144. [CrossRef]

18. Gonzalez-Arnao, M.T.; Martinez-Montero, M.E.; Cruz-Cruz, C.A.; Engelmann, F. Advances in Cryogenic Techniques for the Long-Term Preservation of Plant Biodiversity; Springer: Berlin/Heidelberg, Germany, 2014; pp. 129-170.

19. Fiqa, A.P.; Fauziah, F.; Lestari, d.A.; Budiharta, S. The importance of in-situ conservation area in mining concession in preserving diversity, threatened and potential floras in East Kalimantan, Indonesia. Biodiversitas J. Biol. divers. 2018, 20, 198-210. [CrossRef]

20. Shen, S.; Xu, G.; Li, d.; Clements, d.R.; Zhang, F.; Jin, G.; Wu, J.; Wei, P.; Lin, S.; Xue, d. Agrobiodiversity and in situ conservation in ethnic minority communities of Xishuangbanna in Yunnan Province, Southwest China. J. Ethnobiol. Ethnomed. $2017,13$. [CrossRef] [PubMed]

21. Bekheet, S.A.; Sota, V.; El-Shabrawi, h.M.; El-Minisy, A.M. Cryopreservation of shoot apices and callus cultures of globe artichoke using vitrification Method. J. Genet. Eng. Biotechnol. 2020, 18, 2. [CrossRef]

22. Ramírez-Mosqueda, M.A.; Cruz-Cruz, C.A.; Atlahua-Temoxtle, J.; Bello-Bello, J.J. In vitro conservation and regeneration of Laelia anceps Lindl. S. Afr. J. Bot. 2019, 121, 219-223. [CrossRef]

23. Sánchez-Chiang, N.; Jiménez, V.M. Técnicas de conservación in vitro para el establecimiento de bancos de germoplasma en cultivos tropicales. Agron. Mesoam. 2010, 21, 193-205. [CrossRef]

24. Engelmann, F. Cryopreservation of embryos: An overview. Methods Mol. Biol. 2011, 710, 155-184. [PubMed]

25. Acosta, Y.; Pérez, L.; Linares, C.; hernández, L.; Escalante, d.; Pérez, A.; Zevallos, B.E.; Yabor, L.; Martínez-Montero, M.E.; Cejas, I.; et al. Effects of Teramnus labialis (L.f.) Spreng seed cryopreservation on subsequent seed and seedling growth and biochemistry. Acta Physiol. Plant. 2020, 42, 7. [CrossRef]

26. Agrawal, A.; Singh, S.; Malhotra, E.V.; Meena, d.P.S.; Tyagi, R.K. In Vitro Conservation and Cryopreservation of Clonally Propagated horticultural Species. In Conservation and Utilization of horticultural Genetic Resources; Springer: Singapore, 2019; pp. 529-578.

27. Quatrano, R.S. Freeze-preservation of cultured flax cells utilizing dimethyl sulfoxide. Plant Physiol. 1968, 43, $2057-2061$. [CrossRef] [PubMed]

28. Sakai, A.; Kobayashi, S.; Oiyama, I. Cryopreservation of nucellar cells of navel orange (Citrus sinensis Osb. var. brasiliensis Tanaka) by vitrification. Plant Cell Rep. 1990, 9, 30-33. [CrossRef] 
29. Sugawara, Y.; Sakai, A. Survival of Suspension-cultured sycamore cells cooled to the temperature of liquid nitrogen. Plant Physiol. 1974, 54, 722-724. [CrossRef] [PubMed]

30. Panis, B.; Thinh, N.T. Cryopreservation of Musa germplasm; INIBAP Technical Guideline 5; Bioversity International: Montpellier, France, 2001.

31. Pence, V.C.; Clark, J.R. desiccation, cryopreservation and germination of seeds of the rare wetland species, Plantago cordata Lam. Seed Sci. Technol. 2005, 33, 767-770. [CrossRef]

32. Berjak, P.; Pammenter, N.W. Implications of the lack of desiccation tolerance in recalcitrant seeds. Front. Plant Sci. 2013, 4, 478. [CrossRef] [PubMed]

33. Walters, C.; Pammenter, N.W.; Berjak, P.; Crane, J. desiccation damage, accelerated ageing and respiration in desiccation tolerant and sensitive seeds. Seed Sci. Res. 2001, 11, 135-148. [CrossRef]

34. Pence, V. Cryopreservation of immature embryos of Theobroma cacao. Plant Cell Rep. 1991, 10, 144-147. [CrossRef]

35. Pence, V.C. Evaluating costs for the in vitro propagation and preservation of endangered plants. Vitro Cell. dev. Biol. Plant 2011, 47, 176-187. [CrossRef]

36. Agrawal, A.; Sanayaima, R.; Singh, R.; Tandon, R.; Verma, S.; Tyagi, R.K. Phenotypic and Molecular studies for genetic stability assessment of cryopreserved banana Meristems derived from field and in vitro explant sources. Vitro Cell. dev. Biol. Plant 2014, 50, 345-356. [CrossRef]

37. Sakai, A. development of Cryopreservation Techniques. In Cryopreservation of Tropical Plant Germplasm-Current Research Progress and Applications; Engelmann, F., Takagi, h., Eds.; International Plant Genetic Resources Institute: Roma, Italy, 2000; pp. 1-7, ISBN 9290434287.

38. Kim, h.H.; Cho, E.G.; Baek, h.J.; Kim, C.Y.; Keller, E.R.J.; Engelmann, F. Cryopreservation of garlic shoot tips by vitrification: Effects of dehydration, rewarming, unloading and regrowth conditions. Cryo Lett. 2004, 25, 59-70.

39. Wang, B.; Li, J.W.; Zhang, Z.B.; Wang, R.R.; Ma, Y.L.; Blystad, d.R.; Keller, E.R.J.; Wang, Q.C. Three vitrification-based cryopreservation procedures cause different cryo-injuries to potato shoot tips while all Maintain genetic integrity in regenerants. $J$. Biotechnol. 2014, 184, 47-55. [CrossRef] [PubMed]

40. Nadarajan, J.; van der Walt, K.; Lehnebach, C.A.; Saeiahagh, h.; Pathirana, R. Integrated ex situ conservation strategies for endangered New Zealand Myrtaceae species. N. Zeal. J. Bot. 2020, 1-18. [CrossRef]

41. Volk, G.M.; Walters, C. Plant vitrification solution 2 lowers water content and alters freezing behavior in shoot tips during cryoprotection. Cryobiology 2006, 52, 48-61. [CrossRef]

42. Tanaka, d.; Niino, T.; Uemura, M. Cryopreservation of Plant Genetic Resources. In Advances in Experimental Medicine and Biology; Springer: New York, NY, USA, 2018; Volume 1081, pp. 355-369.

43. Kulus, d. Application of Cryogenic Technologies and Somatic Embryogenesis in the Storage and Protection of valuable Genetic Resources of Ornamental Plants. In Somatic Embryogenesis in Ornamentals and Its Applications; Springer: New delhi, India, 2015; pp. 1-25, ISBN 9788132226833.

44. Panta, A.; Panis, B.; Ynouye, C.; Swennen, R.; Roca, W. development of a PVS2 droplet vitrification Method for potato cryopreservation. Cryo Lett. 2014, 35, 255-266.

45. Yoon, J.W.; Kim, h.H.; Cho, E.G.; Ko, h.C.; hwang, h.S.; Park, Y.E.; Engelmann, F. Cryopreservation of cultivated and wild potato varieties by droplet vitrification procedure. Acta hortic. 2007, 760, 203-208.

46. Engelmann, F. Plant cryopreservation: Progress and prospects. Vitro Cell. dev. Biol. Plant 2004, 40, 427-433. [CrossRef]

47. Wang, M.-R.; Zhang, Z.; Zámečník, J.; Bilavčík, A.; Blystad, d.-R.; haugslien, S.; Wang, Q.-C. droplet-vitrification for shoot tip cryopreservation of shallot (Allium cepa var. aggregatum): Effects of PVS3 and PVS2 on shoot regrowth. Plant Cell Tissue Organ Cult. 2020, 140, 185-195. [CrossRef]

48. Chen, Y.; Wang, J.-H. Cryopreservation of carrot (Daucus carota 1.) cell suspensions and protoplasts by vitrification. Cryo Lett. 2003, 24, 57-64.

49. Fábián, A.; Jäger, K.; darkó, É.; Barnabás, B. Cryopreservation of wheat (Triticum aestivum L.) egg cells by vitrification. Acta Physiol. Plant. 2008, 30, 737-744. [CrossRef]

50. Carmona-Martín, E.; Regalado, J.J.; Perán-Quesada, R.; Encina, C.L. Cryopreservation of rhizome buds of Asparagus officinalis L. (cv. Morado de huétor) and evaluation of their genetic stability. Plant Cell. Tissue Organ Cult. 2018, 133, 395-403. [CrossRef]

51. Lambert, E.; Goossens, A.; Panis, B.; Van Labeke, M.C.; Geelen, d. Cryopreservation of hairy root cultures of Maesa lanceolata and Medicago truncatula. Plant Cell. Tissue Organ Cult. 2009, 96, 289-296. [CrossRef]

52. Dolce, N.R.; hernández-Ramírez, F.; González-Arnao, M.T. Cryopreservation of vanilla (Vanilla planifolia) root-tips: A new alternative for in vitro long-term storage of its germplasm. Acta hortic. 2019, 1234, 203-210. [CrossRef]

53. Popova, E.; Shukla, M.; Kim, h.H.; Saxena, P.K. Root cryobanking: An important tool in plant cryopreservation. Plant Cell. Tissue Organ Cult. 2021, 144, 49-66. [CrossRef]

54. Wowk, B. Thermodynamic aspects of vitrification. Cryobiology 2010, 60, 11-22. [CrossRef] [PubMed]

55. Elliott, G.D.; Wang, S.; Fuller, B.J. Cryoprotectants: A review of the actions and applications of cryoprotective solutes that Modulate cell recovery from ultra-low temperatures. Cryobiology 2017, 76, 74-91. [CrossRef] [PubMed]

56. Wang, S.; Oldenhof, h.; dai, X.; haverich, A.; hilfiker, A.; harder, M.; Wolkers, W.F. Protein stability in stored decellularized heart valve scaffolds and diffusion kinetics of protective Molecules. Acta Proteins Proteom. 2014, 1844, 430-438. [CrossRef] 
57. Teixeira, A.S.; Elena González-Benito, M.; Molina-García, A.D. Glassy state and cryopreservation of mint shoot tips. Biotechnol. Prog. 2013, 29, 707-717. [CrossRef] [PubMed]

58. Teixeira, A.S.; Faltus, M.; Zámečník, J.; González-Benito, M.E.; Molina-García, A.D. Glass transition and heat capacity behaviors of plant vitrification solutions. Thermochim. Acta 2014, 593, 43-49. [CrossRef]

59. Wang, Q.; Tanne, E.; Arav, A.; Gafny, R. Cryopreservation of in vitro-grown shoot tips of grapevine by encapsulation-dehydration. Plant Cell. Tissue Organ Cult. 2000, 63, 41-46. [CrossRef]

60. Bahr, M.M.; Amer, M.S.; Abo-El-Sooud, K.; Abdallah, A.N.; El-Tookhy, O.S. Preservation techniques of stem cells extracellular vesicles: A gate for Manufacturing of clinical grade therapeutic extracellular vesicles and long-term clinical trials. Int. J. Vet. Sci. Med. 2020, 8, 1-8. [CrossRef]

61. Teixeira, A.S.; González, M.E. Tissue and cytoplasm vitrification in cryopreservation Monitored by low temperature scanning electron Microscopy (cryo-SEM). Curr. Microsc. Contrib. Adv. Sci. Technol. 2012, 2, 872-879.

62. Zhang, J.M.; han, L.; Lu, X.X.; Volk, G.M.; Xin, X.; Yin, G.K.; he, J.J.; Wang, L.; Chen, X.L. Cryopreservation of Jerusalem artichoke cultivars using an improved droplet-vitrification Method. Plant Cell. Tissue Organ Cult. 2017, 128, 577-587. [CrossRef]

63. Nishizawa, S. Cryopreservation of asparagus (Asparagus officinalis L.) embryogenic suspension cells and subsequent plant regeneration by a simple freezing Method. Cryo Lett. 1992, 13, 379-388.

64. Suranthran, P.; Gantait, S.; Sinniah, U.R.; Subramaniam, S.; Alwee, S.S.R.S.; Roowi, S.H. Effect of loading and vitrification solutions on survival of cryopreserved oil palm polyembryoids. Plant Growth Regul. 2012, 66, 101-109. [CrossRef]

65. Kim, h.-H.; Lee, Y.-G.; Park, S.-U.; Lee, S.-C.; Baek, h.-J.; Cho, E.-G.; Engelmann, F. development of alternative loading solutions in droplet-vitrification procedures. Cryo Lett. 2009, 30, 291-299.

66. Panis, B.; Strosse, h.; Van den hende, S.; Swennen, R. Sucrose preculture to simplify cryopreservation of banana Meristem cultures. Cryo Lett. 2002, 23, 375-384.

67. Vollmer, R.; Villagaray, R.; Castro, M.; Anglin, N.L.; Ellis, d. Cryopreserved potato shoot tips showed genotype-specific response to sucrose concentration in rewarming solution (RS). Plant Cell Tissue Organ Cult. 2019, 136, 353-363. [CrossRef]

68. Santos, R.R.; Tharasanit, T.; Figueiredo, J.R.; van haeften, T.; van den hurk, R. Preservation of caprine preantral follicle viability after cryopreservation in sucrose and ethylene glycol. Cell Tissue Res. 2006, 325, 523-531. [CrossRef] [PubMed]

69. Nadarajan, J.; Mansor, M.; Krishnapillay, B.; Staines, h.J.; Benson, E.E.; harding, K. Applications of differential scanning calorimetry in developing cryopreservation strategies for Parkia speciosa, a tropical tree producing recalcitrant seeds. Cryo Lett. 2008, 29, 95-110.

70. Tao, d.; Li, P.H. Classification of plant cell cryoprotectants. J. Theor. Biol. 1986, 123, 305-310. [CrossRef]

71. Jiwu, Z.; Ganjun, Y.; Qiuming, Z. Micropropagation and cryopreservation of in vitro shoot tips of "Suizhonghong" papaya. Acta hortic. 2007, 760, 217-224. [CrossRef]

72. Nishizawa, S.; Sakai, A.; Amano, Y.; Matsuzawa, T. Cryopreservation of asparagus (Asparagus officinalis L.) embryogenic suspension cells and subsequent plant regeneration by vitrification. Plant Sci. 1993, 91, 67-73. [CrossRef]

73. Matsumoto, T.; Sakai, A.; Yamada, K. Cryopreservation of in vitro-grown apical Meristems of lily by vitrification. Plant Cell. Tissue Organ Cult. 1995, 41, 237-241. [CrossRef]

74. Uragami, A.; Sakai, A.; Nagai, M.; Takahashi, T. Survival of cultured cells and somatic embryos of Asparagus officinalis cryopreserved by vitrification. Plant Cell Rep. 1989, 8, 418-421. [CrossRef] [PubMed]

75. Sakai, A.; Kobayashi, S.; Oiyama, I. Survival by vitrification of nucellar cells of navel orange (Citrus sinensis var. brasiliensis Tanaka) Cooled to $-196^{\circ}$ C. J. Plant Physiol. 1991, 137, 465-470. [CrossRef]

76. Sakai, A.; Matsumoto, T.; hirai, d.; Niino, T. Newly developed encapsulation-dehydration protocol for plantcryopreservation. Cryo Lett. 2000, 21, 53-62.

77. Meryman, h.T. Cryoprotective agents. Cryobiology 1971, 8, 173-183. [CrossRef]

78. Ishikawa, K.; harata, K.; Mii, M.; Sakai, A.; Yoshimatsu, K.; Shimomura, K. Cryopreservation of zygotic embryos of a Japanese terrestrial orchid (Bletilla striata) by vitrification. Plant Cell Rep. 1997, 16, 754-757. [CrossRef]

79. Towill, L.E. Cryopreservation of isolated mint shoot tips by vitrification. Plant Cell Rep. 1990, 9, 178-180. [CrossRef] [PubMed]

80. Watanabe, K.; Steponkus, P. Vitrification of Oryza sativa L. cell suspensions. Cryo Lett. 1995, 16, $255-262$.

81. Speeckaert, G.; Borges, A.V.; Gypens, N. Salinity and growth effects on dimethylsulfoniopropionate (DMSP) and dimethylsulfoxide (DMSO) cell quotas of Skeletonema costatum, Phaeocystis globosa and Heterocapsa triquetra. Estuar. Coast. Shelf Sci. 2019, 226, 106275. [CrossRef]

82. Wohnhaas, C.T.; Leparc, G.G.; Fernandez-Albert, F.; Kind, d.; Gantner, F.; Viollet, C.; hildebrandt, T.; Baum, P. dMSO cryopreservation is the Method of choice to preserve cells for droplet-based single-cell RNA sequencing. Sci. Rep. 2019, 9, 1-14. [CrossRef]

83. Kulus, d.; Zalewska, M. Cryopreservation as a tool used in long-term storage of ornamental species-A review. Sci. hortic. (Amsterdam) 2014, 168, 88-107. [CrossRef]

84. Teixeira, A.S.; González-Benito, M.E.; Molina-García, A.D. determination of glassy state by cryo-SEM and dSC in cryopreservation of mint shoot tips by encapsulation-dehydration. Plant Cell Tissue Organ Cult. 2014, 119, 269-280. [CrossRef]

85. Pomeisl, K.; Richter, J.; Golan, M.; Kratochvílová, I. Simple syntheses of new pegylated trehalose derivatives as a chemical tool for potential evaluation of cryoprotectant effects on cell Membrane. Molecules 2020, 25, 497. [CrossRef] 
86. Shishova, N.V.; davydova, G.A.; Kombarova, N.A.; davydova, I.B.; Poltavtsev, A.M.; Zaraisky, E.I.; Poltavtseva, R.A. The use of nanosized liposomes from vegetable phospholipids in combination with albumine and some polysaccharides as cryoprotective agents in the course of cryopreservation. IOP Conf. Ser. Mater. Sci. Eng. 2020, 747, 012074. [CrossRef]

87. Grondin, M.; hamel, F.; Averill-Bates, d.A.; Sarhan, F. Wheat proteins improve cryopreservation of rat hepatocytes. Biotechnol. Bioeng. 2009, 103, 582-591. [CrossRef] [PubMed]

88. Wang, J.H.; Bian, h.W.; Zhang, Y.X.; Cheng, h.P. The dual effect of antifreeze protein on cryopreservation of rice (Oryza sativa 1.) embryogenic suspension cells. Cryo Lett. 2001, 22, 175-182.

89. Nadri, T.; Towhidi, A.; Zeinoaldini, S.; Martínez-Pastor, F.; Mousavi, M.; Noei, R.; Tar, M.; Mohammadi Sangcheshmeh, A. Lecithin nanoparticles enhance the cryosurvival of caprine sperm. Theriogenology 2019, 133, 38-44. [CrossRef]

90. Hou, Y.; Lu, C.; dou, M.; Zhang, C.; Chang, h.; Liu, J.; Rao, W. Soft liquid Metal nanoparticles achieve reduced crystal nucleation and ultrarapid rewarming for human bone Marrow stromal cell and blood vessel cryopreservation. Acta Biomater. 2020, 102, 403-415. [CrossRef] [PubMed]

91. Zhang, Y.; Wang, h.; Stewart, S.; Jiang, B.; Ou, W.; Zhao, G.; he, X. Cold-responsive nanoparticle enables intracellular delivery and rapid release of trehalose for organic-solvent-free cryopreservation. Nano Lett. 2019, 19, 9051-9061. [CrossRef] [PubMed]

92. Li, M. Enhancing the efficiency of a PCR using gold nanoparticles. Nucleic Acids Res. 2005, 33, e184. [CrossRef]

93. $\mathrm{Hu}, \mathrm{M} . ;$ hartland, G.V. heat dissipation for Au particles in aqueous solution: Relaxation time versus size. J. Phys. Chem. B 2003, 107, 1284-1284. [CrossRef]

94. Montalbán, I.A.; Olarieta, A.C.; Casillas-Figueroa, F.; Arellano-García, M.E.; Chávez-Santoscoy, A.R.; Pestryakov, A.; Bogdanchikova, N.; Moncaleán, P. Simplified Method to store embryogenic cells: Silver nanoparticles and cryoprotectors elimination effect. Cryobiology 2018, 85, 134. [CrossRef]

95. Ren, L.; deng, S.; Chu, Y.; Zhang, Y.; Zhao, h.; Chen, h.; Zhang, d. Single-wall carbon nanotubes improve cell survival rate and reduce oxidative injury in cryopreservation of Agapanthus praecox embryogenic callus. Plant Methods 2020, 16, 130. [CrossRef]

96. Kulus, d.; Tymoszuk, A. Gold nanoparticles affect the cryopreservation efficiency of in vitro-derived shoot tips of bleeding heart. Plant Cell. Tissue Organ Cult. 2021, 1-15. [CrossRef]

97. Murashige, T.; Skoog, F. A Revised Medium for rapid growth and bio assays with tobacco tissue cultures. Physiol. Plant. 1962, 15, 473-497. [CrossRef]

98. Digilio, A. Crioconservación de variedades nativas de Solanum tuberosum ssp. andigenum Juz. \& Bukasov. Master's Thesis, Universidad Nacional de Mar del Plata, Buenos Aires, Argentina, 2014.

99. Panta, A.; Panis, B.; Ynouye, C.; Swennen, R.; Roca, W.; Tay, d.; Ellis, d. Improved cryopreservation Method for the long-term conservation of the world potato germplasm collection. Plant Cell. Tissue Organ Cult. 2015, 120, 117-125. [CrossRef]

100. Niino, T.; Arizaga, M.V. Cryopreservation for preservation of potato genetic resources. Breed. Sci. 2015, 65, 41-52. [CrossRef] [PubMed]

101. Mathew, L.; Burritt, d.J.; McLachlan, A.; Pathirana, R. Combined pre-treatments enhance antioxidant Metabolism and improve survival of cryopreserved kiwifruit shoot tips. Plant Cell. Tissue Organ Cult. 2019, 138, 193-205. [CrossRef]

102. Bi, W.L.; Pan, C.; hao, X.Y.; Cui, Z.H.; Kher, M.M.; Marković, Z.; Wang, Q.C.; Teixeira da Silva, J.A. Cryopreservation of grapevine (Vitis spp.)-A review. Vitro Cell. dev. Biol. Plant 2017, 53, 449-460. [CrossRef]

103. Ibáñez, M.A.; Alvarez-Mari, A.; Rodríguez-Sanz, h.; Kremer, C.; González-Benito, M.E.; Martín, C. Genetic and epigenetic stability of recovered mint apices after several steps of a cryopreservation protocol by encapsulation-dehydration. A new approach for epigenetic analysis. Plant Physiol. Biochem. 2019, 143, 299-307. [CrossRef]

104. Li, J.W.; Chen, h.Y.; Li, X.Y.; Zhang, Z.; Blystad, d.R.; Wang, Q.C. Cryopreservation and evaluations of vegetative growth, Microtuber production and genetic stability in regenerants of purple-fleshed potato. Plant Cell. Tissue Organ Cult. 2017, 128, 641-653. [CrossRef]

105. Yamamoto, S.; Rafique, T.; Priyantha, W.S.; Fukui, K.; Matsumoto, T.; Niino, T. development of a cryopreservation procedure using aluminium cryo-plates. Cryo Lett. 2011, 32, 256-265.

106. Niino, T.; Yamamoto, S.-I.; Fukui, K.; Martínez, C.R.C.; Arizaga, M.V.; Matsumoto, T.; Engelmann, F. dehydration improves cryopreservation of Mat rush (Juncus decipiens Nakai) basal stem buds on cryo-plates. Cryo Lett. 2013, 549-560.

107. Matsumoto, T.; Yamamoto, S.-I.; Fukui, K.; Rafique, T.; Engelmann, F.; Niino, T. Cryopreservation of persimmon shoot tips from dormant buds using the d cryo-plate technique. Hortic. J. 2015, 1-5. [CrossRef]

108. Niino, T.; Watanabe, K.; Nohara, N.; Rafique, T.; Yamamoto, S.; Fukui, K.; Arizaga, M.V.; Martinez, C.R.C.; Matsumoto, T.; Engelmann, F.; et al. Cryopreservation of Mat rush lateral buds by air dehydration using aluminum cryo-plate. Plant Biotechnol. 2014, 31, 281-287. [CrossRef]

109. Rafique, T.; Yamamoto, S.I.; Fukui, K.; Tanaka, d.; Arizaga, M.V.; Abbas, M.; Matsumoto, T.; Niino, T. Cryopreservation of shoot-tips from different sugarcane varieties using d cryo-plate technique. Pakistan J. Agric. Sci. 2016, 53, 151-158. [CrossRef]

110. Nadarajan, J.; Pritchard, h.W. Biophysical characteristics of successful oilseed embryo cryoprotection and cryopreservation using vacuum infiltration vitrification: An innovation in plant cell preservation. PLoS ONE 2014, 9, 96169. [CrossRef] [PubMed]

111. Vozovyk, K.; Bobrova, O.; Prystalov, A.; Shevchenko, N.; Kuleshova, L. Amorphous state stability of plant vitrification solutions. Biologija 2020, 66. [CrossRef]

112. Kulus, d. Managing plant genetic resources using low and ultra-low temperature storage: A case study of tomato. Biodivers. Conserv. 2019, 28, 1003-1027. [CrossRef] 
113. Sgueglia, A.; Gentile, A.; Frattarelli, A.; Germanà, M.A.; Caboni, E. Cryopreservation of Italian cultivars of hazelnut. Acta hortic. 2021, 1307, 159-162. [CrossRef]

114. Bidabadi, S.S.; Mohan Jain, S. Cellular, Molecular, and physiological aspects of in vitro plant regeneration. Plants 2020, 9, 702. [CrossRef]

115. Manokari, M.; Priyadharshini, S.; Jogam, P.; dey, A.; Shekhawat, M.S. Meta-topolin and liquid Medium Mediated enhanced Micropropagation via ex vitro rooting in Vanilla planifolia Jacks. ex Andrews. Plant Cell. Tissue Organ Cult. 2021, 1-14. [CrossRef]

116. Zaytseva, Y.G.; Ambros, E.V.; Novikova, T.I. Meta-topolin:Advantages and disadvantages for In Vitro Propagation. In Meta-topolin: A Growth Regulator for Plant Biotechnology and Agriculture; Springer: Singapore, 2021; pp. 119-141.

117. Ahmad, A.; Anis, M. Meta-topolin improves in vitro Morphogenesis, rhizogenesis and biochemical analysis in Pterocarpus Marsupium Roxb.: A potential drug-yielding tree. J. Plant Growth Regul. 2019, 38, 1007-1016. [CrossRef]

118. Khanam, M.N.; Javed, S.B.; Anis, M.; Alatar, A.A. Meta-topolin induced in vitro regeneration and Metabolic profiling in Allamanda cathartica L. Ind. Crops Prod. 2020, 145, 111944. [CrossRef]

119. Edesi, J.; Maria Pirttilä, A.; häggman, h. Modified light spectral conditions prior to cryopreservation alter growth characteristics and cryopreservation success of potato (Solanum tuberosum L.) shoot tips in vitro. Plant Cell Tissue Organ Cult. 2017, 128, 409-421. [CrossRef]

120. Mølmann, J.A.B.; Johansen, T.J. Sprout growth inhibition and photomorphogenic development of potato seed tubers (Solanum tuberosum L.) under different LED light colours. Potato Res. 2020, 63, 199-215. [CrossRef]

121. Volk, G.M. Application of functional genomics and proteomics to plant cryopreservation. Curr. Genomics 2010, 11, 24-29. [CrossRef] [PubMed]

122. Uchendu, E.E.; Muminova, M.; Gupta, S.; Reed, B.M. Antioxidant and anti-stress compounds improve regrowth of cryopreserved Rubus shoot tips. Vitro Cell. dev. Biol. Plant 2010, 46, 386-393. [CrossRef]

123. Tymoszuk, A.; Miler, N. Silver and gold nanoparticles impact on in vitro adventitious organogenesis in chrysanthemum, gerbera and Cape Primrose. Sci. hortic. (Amsterdam) 2019, 257. [CrossRef]

124. Tymoszuk, A.; Wojnarowicz, J. Zinc oxide and zinc oxide nanoparticles impact on in vitro germination and seedling growth in Allium cepa L. Materials (Basel) 2020, 13, 2784. [CrossRef]

125. Tian, h.; Ghorbanpour, M.; Kariman, K. Manganese oxide nanoparticle-induced changes in growth, redox reactions and elicitation of antioxidant Metabolites in deadly nightshade (Atropa belladonna L.). Ind. Crops Prod. 2018, 126, 403-414. [CrossRef]

126. Gupta, S.D.; Agarwal, A.; Pradhan, S. Phytostimulatory effect of silver nanoparticles (AgNPs) on rice seedling growth: An insight from antioxidative enzyme activities and gene expression patterns. Ecotoxicol. Environ. Saf. 2018, 161, 624-633. [CrossRef] [PubMed]

127. Tymoszuk, A.; Kulus, d. Silver nanoparticles induce genetic, biochemical, and phenotype variation in chrysanthemum. Plant Cell. Tissue Organ Cult. 2020, 143, 331-344. [CrossRef]

128. Zhang, Z.; Ke, M.; Qu, Q.; Peijnenburg, W.J.G.M.; Lu, T.; Zhang, Q.; Ye, Y.; Xu, P.; du, B.; Sun, L.; et al. Impact of copper nanoparticles and ionic copper exposure on wheat (Triticum aestivum L.) root Morphology and antioxidant response. Environ. Pollut. 2018, 239, 689-697. [CrossRef] [PubMed]

129. Vandenbussche, B.; Weyens, G.; de Proft, M. Cryopreservation of in vitro sugar beet (Beta vulgaris L.) shoot tips by a vitrification technique. Plant Cell Rep. 2000, 19, 1064-1068. [CrossRef] [PubMed]

130. Yamuna, G.; Sumathi, V.; Geetha, S.P.; Praveen, K.; Swapna, N.; Babu, K.N. Cryopreservation of in vitro grown shoots of ginger (Zingiber officinale Rosc.). Cryo Lett. 2007, 28, 241-252.

131. Sánchez, d.F.; Panta, A.; Tay, d.; Roca, W. Cryopreservation of ulluco (Ullucus tuberosus cal.) and oca (Oxalis tuberosa Mol.) shoot tips using the PVS2 droplet-vitrification Method. Acta hortic. 2011, 908, 339-346. [CrossRef]

132. Arizaga, M.V.; Yamamoto, S.-I.; Tanaka, d.; Fukui, K.; Nohara, N.; Nishikawa, T.; Watanabe, K.; Niino, T. Cryopreservation of in vitro shoot tips of ulluco (Ullucus tuberosus Cal.) using d cryo-plate Method. Cryo Lett. 2017, 9, 419-427.

133. Romadanova, N.; Kushnarenko, S.; Karasholakova, L. development of a common PVS2 vitrification Method for cryopreservation of several fruit and vegetable crops. Vitro Cell. dev. Biol. Plant 2017, 53, 382-393. [CrossRef]

134. Pipithsangchan, K.; Chareonsap, P.P.; Reanhatthakam, K.; Jutamas, P.; Narkprasert, d.; Thammasiri, K. Cryopreservation technique for lettuce, Chinese cabbage, flowering white cabbage, Chinese kale and pak choi seeds by encapsulation-dehydration. Acta hortic. 2019, 1234, 189-194. [CrossRef]

135. Senula, A.; Büchner, d.; Keller, E.R.J.; Nagel, M. An improved cryopreservation protocol for Mentha spp. based on PVS3 as the cryoprotectant. Cryo Lett. 2018, 9, 345-353.

136. Pipithsangchan, K.; Chareonsap, P.P.; Reanhatthakam, K.; Jutamas, P.; Narkprasert, d.; Thammasiri, K. Cryopreservation technique of chilli seeds by vitrification. Acta hortic. 2019, 1234, 145-148. [CrossRef]

137. Pérez, J.; Araya-Valverde, E.; Garro, G.; Abdelnour-Esquivel, A. Analysis of stress indicators during cryopreservation of seeds of landrace Maize (Zea Mays). Cryo Lett. 2017, 38, 445-454.

138. Arguedas, M.; Villalobos, A.; Gómez, d.; hernández, L.; Zevallos, B.E.; Cejas, I.; Yabor, L.; Martínez-Montero, M.E.; Lorenzo, J.C. Field performance of cryopreserved seed-derived Maize plants. Cryo Lett. 2018, 39, 366-370.

139. Bettoni, J.C.; Bonnari, R.; Shepherd, A.; Kretzschmar, A.A.; Volk, G.M. Cryopreservation of grapevine (Vitis spp.) shoot tips from growth chamber-sourced plants and histological observations. Vitis 2019, 58, 71-78. [CrossRef] 
140. Wang, M.-R.; Zhang, Z.; haugslien, S.; Sivertsen, A.; Rasmussen, M.; Wang, Q.-C.; Blystad, d.-R. Cryopreservation of shallot (Allium cepa var. aggregatum) shoot tips by droplet-vitrification. Acta hortic. 2019, 1234, 241-248. [CrossRef]

141. Liu, X.-X.; Mou, S.-W.; Cheng, Z.-H. Effect of cryopreservation on plant growth, bulb characteristics, and virus reduction of garlic (Allium Sativum L.). Cryo Lett. 2019, 40, 322-332.

142. Keller, E.R.J. Improvement of cryopreservation results in garlic using low temperature preculture and high-quality in vitro plantlets. Cryo Lett. 2005, 26, 357-366.

143. Kim, h.H.; Lee, J.K.; Yoon, J.W.; Ji, J.J.; Nam, S.S.; hwang, h.S.; Cho, E.G.; Engelmann, F. Cryopreservation of garlic bulbil primordia by the droplet-vitrification procedure. Cryo Lett. 2006, 27, 143-153.

144. Kim, h.H.; Popova, E.; Shin, d.J.; Yi, J.Y.; Kim, C.H.; Lee, J.S.; Yoon, M.K.; Engelmann, F. Cryobanking of Korean allium germplasm collections: Results from a 10 year experience. Cryo Lett. 2012, 33, 45-57.

145. Kaczmarczyk, A.; Rokka, V.-M.; Keller, E.R.J. Potato Shoot Tip Cryopreservation. A Review. Potato Res. 2011, 54, 45-79. [CrossRef]

146. Bissati, S.; Boudjenah, S.; Morisset, C.; Chenchouni, h. does pre-culture in sugar-rich Media affect carbohydrate content and postthawing recovery rate of cryopreserved potato (Solanum phureja) shoot tips? J. King Saud Univ. Sci. 2020, 32, 1917-1924. [CrossRef]

147. Uchendu, E.E.; Shukla, M.; Saxena, P.K.; Keller, J.E.R. Cryopreservation of potato Microtubers: The critical roles of sucrose and desiccation. Plant Cell Tissue Organ Cult. 2016, 124, 649-656. [CrossRef]

148. Keller, E.R.J.; dreiling, M. Potato cryopreservation in Germany-Using the droplet Method for the establishment of a new large collection. Acta hortic. 2003, 623, 193-200. [CrossRef]

149. Kushnarenko, S.; Romadanova, N.; Aralbayeva, M.; Zholamanova, S.; Alexandrova, A.; Karpova, O. Combined ribavirin treatment and cryotherapy for efficient Potato virus $\mathrm{M}$ and Potato virus S eradication in potato (Solanum tuberosum L.) in vitro shoots. Vitro Cell. dev. Biol. Plant 2017, 53, 425-432. [CrossRef]

150. Ayala hernandez, d.D.; Ruiz Sáenz, d.R.; Cruz Gutiérrez, E.J.; Lopez delgado, h.A. Ácido salicílico induce tolerancia al estrés por criogenia en Solanum tuberosum. Rev. Mex. Ciencias Agrícolas 2019, 10, 1505-1515. [CrossRef]

151. Wang, M.-R.; hamborg, Z.; Slimestad, R.; Elameen, A.; Blystad, d.-R.; haugslien, S.; Skjeseth, G.; Wang, Q.-C. Assessments of rooting, vegetative growth, bulb production, genetic integrity and biochemical compounds in cryopreserved plants of shallot. Plant Cell Tissue Organ Cult. 2021, 144, 123-131. [CrossRef]

152. Liu, X.-X.; Wen, Y.-B.; Cheng, Z.-H.; Mou, S.-W. Establishment of a garlic cryopreservation protocol for shoot apices from adventitious buds in vitro. Sci. hortic. (Amsterdam) 2017, 226, 10-18. [CrossRef]

153. Seo, J.H.; Naing, A.H.; Jeon, S.M.; Kim, C.K. Anti-freezing-protein type III strongly influences the expression of relevant genes in cryopreserved potato shoot tips. Plant Mol. Biol. 2018, 97, 347-355. [CrossRef] [PubMed]

154. Köpnick, C.; Grübe, M.; Stock, J.; Senula, A.; Mock, h.-P.; Nagel, M. Changes of soluble sugars and ATP content during dMSO droplet freezing and PVS3 droplet vitrification of potato shoot tips. Cryobiology 2018, 85, 79-86. [CrossRef] [PubMed]

155. Lazo Javalera, M.F.; Tiznado hernández, M.E.; Vargas Arispuro, I.; Martínez Téllez, M.Á.; Islas Osuna, M.A.; hernández Oñate, M.Á.; Rivera domínguez, M. Genetic stability of cryopreserved grapevine (Vitis vinifera L.) genome by vitrification Method. J. Agric. Sci. Technol. B 2016, 6, 380-386. [CrossRef]

156. Edesi, J.; Kotkas, K.; Pirttilä, A.M.; häggman, h. does light spectral quality affect survival and regeneration of potato (Solanum tuberosum L.) shoot tips after cryopreservation? Plant Cell. Tissue Organ Cult. 2014, 119, 599-607. [CrossRef]

157. Folgado, R.; Sergeant, K.; Renaut, J.; Swennen, R.; hausman, J.-F.; Panis, B. Changes in sugar content and proteome of potato in response to cold and dehydration stress and their implications for cryopreservation. J. Proteomics 2014, 98, 99-111. [CrossRef]

158. Folgado, R.; Panis, B.; Sergeant, K.; Renaut, J.; Swennen, R.; hausman, J.-F. Unravelling the effect of sucrose and cold pretreatment on cryopreservation of potato through sugar analysis and proteomics. Cryobiology 2015, 71, 432-441. [CrossRef]

159. Tanaka, d.; Sakuma, Y.; Yamamoto, S.; Valle Arizaga, M.; Niino, T.; Matsumoto, T. development of $-80{ }^{\circ} \mathrm{C}$ storage for Allium shoot tips using d cryo-plate Method. Plant Cell Tissue Organ Cult. 2021, 144, 115-122. [CrossRef]

160. Yamamoto, S.I.; Rafique, T.; Arizaga, M.V.; Fukui, K.; Gutierrez, E.J.C.; Martinez, C.R.C.; Watanabe, K.; Niino, T. The aluminum cryo-plate increases efficiency of cryopreservation protocols for potato shoot tips. Am. J. Potato Res. 2015, 92, 250-257. [CrossRef]

161. Morel, G.; Wetmore, R.H. Fern callus tissue culture. Am. J. Bot. 1951, 38, 141-143. [CrossRef]

162. Tendille, C.; Lecerf, M. La Multiplication vegetative de L'Asperge (Asparagus officinalis L.). action de divers facteurs, en particu-lier de la nutrition minerale, sur le developpement des Meristemes d'asperge, sur la croissance des plantu-les issues de ces Meristemes et sur la p. ANN. Amelior. Plantes 1974, 24, 269-282.

163. Ren, R.; Li, Z.; Zhang, L.; Zhou, h.; Jiang, X.; Liu, Y. Enzymatic and nonenzymatic antioxidant systems impact the viability of cryopreserved Paeonia suffruticosa pollen. Plant Cell. Tissue Organ Cult. 2021, 144, 233-246. [CrossRef]

164. Wen, B.; Cai, C.; Wang, R.; Song, S.; Song, J. Cytological and physiological changes in recalcitrant Chinese fan palm (Livistona chinensis) embryos during cryopreservation. Protoplasma 2012, 249, 323-335. [CrossRef] [PubMed]

165. Wen, B.; Wang, R.; Cheng, h.; Song, S. Cytological and physiological changes in orthodox Maize embryos during cryopreservation. Protoplasma 2010, 239, 57-67. [CrossRef] [PubMed]

166. Subbarayan, K.; Rolletschek, h.; Senula, A.; Ulagappan, K.; hajirezaei, M.R.; Keller, E.R.J. Influence of oxygen deficiency and the role of specific amino acids in cryopreservation of garlic shoot tips. BMC Biotechnol. 2015, 15, 1-9. [CrossRef] [PubMed]

167. Solov'eva, A.I.; dolgikh, Y.I.; Vysotskaya, O.N.; Popov, A.S. Patterns of ISSR and REMAP dNA Markers after cryogenic preservation of spring wheat calli by dehydration Method. Russ. J. Plant Physiol. 2011, 58, 423-430. [CrossRef] 
168. Maki, S.; hirai, Y.; Niino, T.; Matsumoto, T. Assessment of Molecular genetic stability between long-term cryopreserved and tissue cultured wasabi (Wasabia japonica) plants. Cryo Lett. 2015, 36, 318-324.

169. Zevallos, B.; Cejas, I.; Valle, B.; Yabor, L.; Aragón, C.; Engelmann, F.; Martínez, M.E.; Lorenzo, J.C. Short-term liquid nitrogen storage of wild tomato (Solanum lycopersicum Mill.) seeds Modifies the levels of phenolics in 7 day-old seedlings. Sci. hortic. (Amsterdam) 2013, 160, 264-267. [CrossRef]

170. Villalobos, A.; Arguedas, M.; Escalante, d.; Martínez, J.; Zevallos, B.E.; Cejas, I.; Yabor, L.; Martínez-Montero, M.S.E.; Lorenzo, J.C. Cryopreservation of sorghum seeds Modifies germination and seedling growth but not field performance of adult plants. Artic. J. Appl. Bot. Food Qual. 2019, 92, 94-99. [CrossRef]

171. Ritonga, F.N.; Chen, S. Physiological and Molecular Mechanism involved in cold stress tolerance in plants. Plants 2020, 9, 560. [CrossRef] [PubMed] 